University of Nebraska - Lincoln

DigitalCommons@University of Nebraska - Lincoln

Publications from USDA-ARS / UNL Faculty

U.S. Department of Agriculture: Agricultural

Research Service, Lincoln, Nebraska

2015

\title{
Growing the urban forest: tree performance in response to biotic and abiotic land management
}

\author{
Emily E. Oldfield \\ Yale University, emily.oldfield@yale.edu \\ Alexander J. Felson \\ Yale University \\ D.S. Novem Auyeung \\ NYC Department of Parks \& Recreation, NYC Urban Field Station, Bayside, NY \\ Thomas W. Crowther \\ Yale University \\ Nancy F. Sonti \\ USDA Forest Service, Northern Research Station, NYC Urban Field Station, Bayside, NY \\ See next page for additional authors
}

Follow this and additional works at: https://digitalcommons.unl.edu/usdaarsfacpub

Oldfield, Emily E.; Felson, Alexander J.; Auyeung, D.S. Novem; Crowther, Thomas W.; Sonti, Nancy F.; Harada, Yoshiki; Maynard, Daniel S.; Sokol, Noah W.; Ashton, Mark S.; Warren, Robert J. II; Hallett, Richard A.; and Bradford, Mark A., "Growing the urban forest: tree performance in response to biotic and abiotic land management" (2015). Publications from USDA-ARS / UNL Faculty. 1536.

https://digitalcommons.unl.edu/usdaarsfacpub/1536

This Article is brought to you for free and open access by the U.S. Department of Agriculture: Agricultural Research Service, Lincoln, Nebraska at DigitalCommons@University of Nebraska - Lincoln. It has been accepted for inclusion in Publications from USDA-ARS / UNL Faculty by an authorized administrator of DigitalCommons@University of Nebraska - Lincoln. 


\section{Authors}

Emily E. Oldfield, Alexander J. Felson, D.S. Novem Auyeung, Thomas W. Crowther, Nancy F. Sonti, Yoshiki Harada, Daniel S. Maynard, Noah W. Sokol, Mark S. Ashton, Robert J. Warren II, Richard A. Hallett, and Mark A. Bradford 


\title{
Growing the urban forest: tree performance in response to biotic and abiotic land management
}

\author{
Emily E. Oldfield ${ }^{1,2}$, Alexander J. Felson ${ }^{1,3}$, D. S. Novem Auyeung ${ }^{4}$, Thomas W. Crowther ${ }^{1}$, \\ Nancy F. Sonti ${ }^{5,6}$, Yoshiki Harada ${ }^{1,7}$, Daniel S. Maynard ${ }^{1}$, Noah W. Sokol ${ }^{1}$, Mark S. Ashton ${ }^{1}$, \\ Robert J. Warren II $^{8}$, Richard A. Hallett ${ }^{9}$, Mark A. Bradford ${ }^{1}$
}

Forests are vital components of the urban landscape because they provide ecosystem services such as carbon sequestration, storm-water mitigation, and air-quality improvement. To enhance these services, cities are investing in programs to create urban forests. A major unknown, however, is whether planted trees will grow into the mature, closed-canopied forest on which ecosystem service provision depends. We assessed the influence of biotic and abiotic land management on planted tree performance as part of urban forest restoration in New York City, U.S.A. Biotic treatments were designed to improve tree growth, with the expectation that higher tree species composition (six vs. two) and greater stand complexity (with shrubs vs. without) would facilitate tree performance. Similarly, the abiotic treatment (compost amendment vs. without) was expected to increase tree performance by improving soil conditions. Growth and survival was measured for approximately 1,300 native saplings across three growing seasons. The biotic and abiotic treatments significantly improved tree performance, where shrub presence increased tree height for five of the six tree species, and compost increased basal area and stem volume of all species. Species-specific responses, however, highlighted the difficulty of achieving rapid growth with limited mortality. Pioneer species had the highest growth in stem volume over 3 years (up to 3,500\%), but also the highest mortality (up to $40 \%$ ). Mid-successional species had lower mortality $(<16 \%)$, but also the slowest growth in volume (approximately $500 \%$ in volume). Our results suggest that there will be trade-offs between optimizing tree growth versus survival when implementing urban tree planting initiatives.

Key words: afforestation, compost, ecosystem services, green infrastructure, native species, restoration, urban forestry

\section{Implications for Practice}

- Species generally conform to their ecological growth rate classifications for non-urban systems, highlighting the utility of these principles in predicting growth patterns and species interactions in urban afforestation initiatives.

- Pioneer species had the highest incremental growth in basal area, height, and stem volume. They also suffered the highest mortality, highlighting that land managers will need to balance trade-offs in achieving survival versus growth goals.

- Planting shrubs alongside trees at high stocking densities can lead to greater growth in the height of planted trees to achieve faster canopy closure.

- The use of compost can increase tree growth; however, it may take multiple years for compost effects to manifest.

\section{Introduction}

As urban populations continue to grow, investing in green infrastructure has become a policy imperative for large cities across the globe. In the pursuit of sustainability and resilience, cities are investing in projects intended to support a range of ecosystem services such as improving air quality, reducing the urban heat island effect, sequestering carbon, increasing storm-water infiltration, and promoting wildlife habitat (Nowak 2006; Pataki et al. 2011; Gaffin et al. 2012). Planting trees is one of the primary means to achieve these services, and the benefits of the urban tree canopy are increasingly recognized (McPherson et al.

Author contributions: AJF, MAB, EEO, RAH, MSA conceived and designed the research; all authors performed field work; EEO analyzed data; DSM, RJW provided statistical guidance; EEO wrote the first draft of the manuscript; all authors contributed to data interpretation and paper writing.

${ }^{1}$ School of Forestry and Environmental Studies, Yale University, 370 Prospect Street, New Haven, CT 06511, U.S.A.

${ }^{2}$ Address correspondence to E. Oldfield, email emily.oldfield@yale.edu

${ }^{3}$ School of Architecture, Yale University, 180 York Street, New Haven, CT 06511, U.S.A.

${ }^{4}$ NYC Department of Parks \& Recreation, NYC Urban Field Station, 431 Walter Reed Road, Bayside, NY 11359, U.S.A.

${ }^{5}$ USDA Forest Service, Northern Research Station, NYC Urban Field Station, 431 Walter Reed Road, Bayside, NY 11359, U.S.A.

${ }^{6}$ USDA Forest Service, Northern Research Station, Baltimore Field Station, 5523 Research Park Drive, Baltimore, MD 21228, U.S.A.

${ }^{7}$ Department of Horticulture, Cornell University, 134 Plant Sciences Building, Ithaca, NY 14853, U.S.A.

${ }^{8}$ Department of Biology, SUNY Buffalo State, 1300 Elmwood Avenue, Buffalo, NY 14222, U.S.A.

${ }^{9}$ USDA Forest Service, Northern Research Station, Durham, NH 03824, U.S.A.

(C) 2015 Society for Ecological Restoration

doi: $10.1111 /$ rec. 12230

Supporting information at:

http://onlinelibrary.wiley.com/doi/10.1111/rec.12230/suppinfo 
1997; Nowak et al. 2001; McPherson et al. 2005). Researchers have quantified the economic value of the urban forest canopy, finding that trees provide millions of U.S. dollars worth of ecosystem service benefits (Brack 2002; Nowak et al. 2002). To bolster urban tree canopy, cities are now investing equally large sums of money in street tree planting programs and the creation of new urban forests (Pataki et al. 2011; Nowak 2012). Indeed, a number of afforestation efforts in cities such as New York City, London, Los Angeles, and Auckland are investing in the creation of closed-canopy urban forests, planting native tree saplings with the expectation that they will develop into a mature forest capable of providing a host of ecosystem services to the urban landscape (Oldfield et al. 2013).

To construct urban forests, land managers generally choose trees native to the region with no known susceptibility to pests and pathogens. The planting choices for these new urban forests typically contain assemblages of native species growing in an environment without a natural analogue. As such, it is difficult to project with certainty how well the planted trees will perform in the urban environment. Yet the success of these programs relies on the creation of closed-canopy forests that will eventually attain maturity, as mature trees provide the majority of environmental benefits (Nowak et al. 2002; Troxel et al. 2013). Research in non-urban systems shows that mixed species plantings can provide ecological benefits over monocultures, including increased biodiversity, improved nutrient cycling and soil fertility, and increased carbon sequestration (Forrester et al. 2006; Piotto 2008). These benefits, however, depend on the species planted, the way they interact with each other, and local site contingencies (Piotto 2008).

Using known ecological growth rate and shade tolerance classifications can help guide expectations for forest growth. However, a host of stressors in the urban environment can threaten the viability of native plantings. These include degraded soils, drought, and aggressive exotics that can outcompete the natives (Robinson \& Handel 2000; Rawlinson et al. 2004; Sullivan et al. 2009; Overdyck \& Clarkson 2012). These issues highlight the fact that there is no prior knowledge that the planted vegetation is suitable to the site (Robinson \& Handel 2000; Kowarik 2011). What is needed are studies that redress the paucity of data assessing the success of native, urban planting efforts (Oldfield et al. 2013). Without such data, urban afforestation projects are investments that lack sufficient information informing the likelihood of success. A key question is then: will planted native trees grow and create forests capable of providing the intended ecosystem services? Understanding how species will interact with each other and with their environment is key to designing successful afforestation programs (Piotto 2008), in non-urban and urban systems alike.

This study - a research component of New York City's MillionTreesNYC Initiative-explored the performance of an assemblage of six native species under various treatments known to impact tree growth. Species composition explored the effect of the number of planted species (two vs. six) on tree performance. Given research highlighting greater productivity of trees planted in mixture (Forrester et al. 2006; Piotto 2008), we expected that trees within six species plots would demonstrate improved performance compared with trees within two species plots. The addition of shrubs tested the impact of competitive and facilitative interactions between planted shrubs and trees, which could either lead to reduced or enhanced tree performance when compared to plots without shrubs (Vandermeer 1989). The addition of compost tested whether plots receiving amendment promoted vigorous growth and biomass accumulation for carbon storage, given positive effects of compost on water availability (Ryals \& Silver 2013). We assessed the performance of approximately 1,300 individuals of six native species across 54 experimental plots in 2011, 2012, and 2013 , following planting of the 3- to 5-year-old seedlings in the autumn of 2010 .

\section{Methods}

\section{Site Description and Experimental Design}

The experiment, the New York City Afforestation Project (NY-CAP), is located in Kissena Corridor Park $\left(40^{\circ} 44^{\prime} \mathrm{N}\right.$, $73^{\circ} 49^{\prime} \mathrm{W}$; $114 \mathrm{~cm} \mathrm{MAP,} 13^{\circ} \mathrm{C}$ MAT), a 40 -ha urban park in eastern Queens, New York, U.S.A. The project was developed as a "designed experiment," which incorporates ecological research with urban design (Felson et al. 2013). The park contains 54 research plots (Fig. 1A). The Natural Resources Conservation Service (NRCS) classified soils across Kissena as Laguardia-Ebbets complex, meaning the soils are well drained, loamy-skeletal to coarse-loamy fill soils with more than $10 \%$ human-derived artifacts. Our research plots fall in the Ebbets soil series, characterized by less than $35 \%$ of coarse fragments (NRCS 2009).

The research plots were separated into eight different treatments, consisting of a crossed arrangement of tree species composition (six species vs. two species), stand complexity (with shrubs vs. without), and soil amendment (with compost vs. without). We refer to these treatments as composition, shrub, and compost. Note that this experiment was not designed to test mechanisms of diversity on productivity (e.g. sampling effect or complementarity), but rather to evaluate if species composition in plots had an effect on performance of the planted trees. Replication is uneven and is organized as follows: two species/no shrubs/no compost, $n=9$; two species/no shrubs/compost, $n=5$; two species/shrubs/no compost, $n=9$; two species/shrubs/compost, $n=5$; six species/no shrubs/no compost, $n=5$; six species/no shrubs/compost, $n=8$; six species/shrubs/no compost, $n=5$; six species/shrubs/compost, $n=8$. Each plot is $15 \times 15 \mathrm{~m}\left(225 \mathrm{~m}^{2}\right)$ and includes 56 trees planted $2.1 \mathrm{~m}$ apart from each other. The two species plots include 28 Tilia americana and 28 Quercus rubra (Fig. 1B). The six species plots are composed of 8 individuals of T. americana and $Q$. rubra, plus 10 individuals each of Celtis occidentalis, Carya spp., Prunus serotina, and Quercus alba (Fig. 1C). As the NY-CAP exists within a heavily used urban park, the plot layout was designed as an offset grid (Fig. 1B \& 1C) to both facilitate research and serve as an esthetic landscape amenity (Felson et al. 2013). Tree species selected for this project had to meet the following criteria: 
(A)

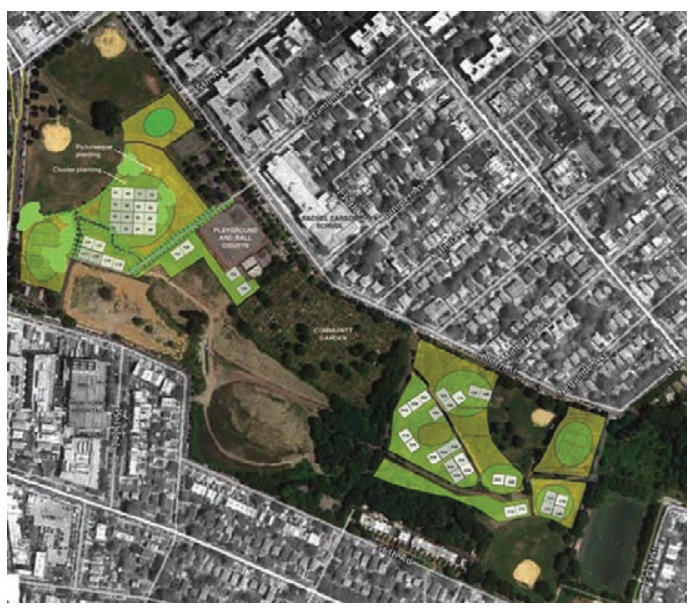

(B)

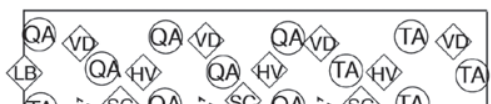

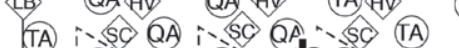

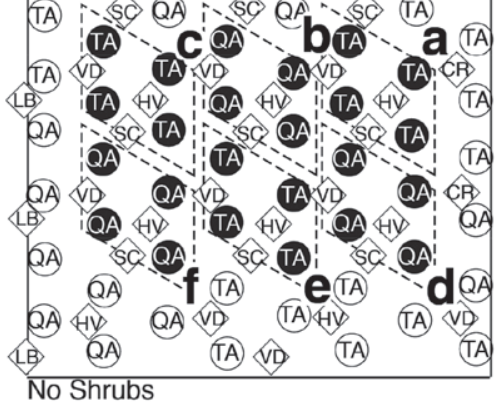

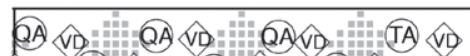

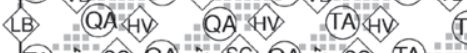

(TA)

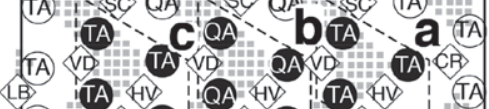

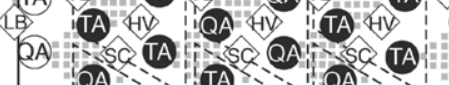

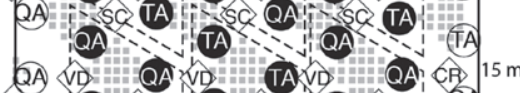

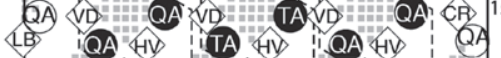

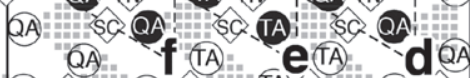

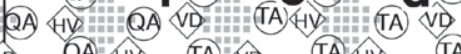

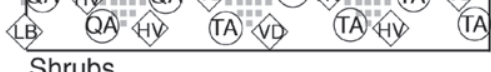

\section{Composition (2 species) \\ QBi Quercus rubra \\ (A) Tilia americana}

vib Viburnum dentatum $\$ y$ Hamemelis virginiana Sambucus canadensis
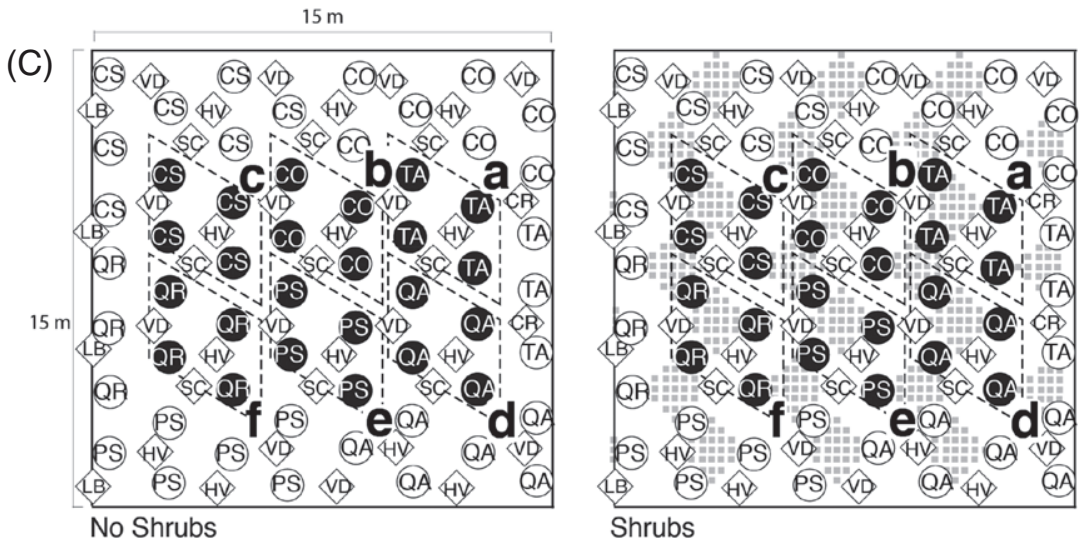

\section{Composition (6 species)}
Q8) Quercus rubra
CS Carya sp
Prunus serotina
(1A Tilia americana
C. Celtis occidentalis
Quercus alba

vig Viburnum dentatum

सHy Hamemelis virginiana

sc. Sambucus canadensis

Figure 1. (A) An aerial view of the afforestation research plots in Kissena Corridor Park in Queens, New York, U.S.A.; (B) plot layout of the planted trees in two species plots; and (C) layout of the planted trees in six species plots. Measurements of diameter, height, and stem volume were taken for the central 24 trees in each plot located in the subplots labeled a-f. 
all species are native to the region, and have no known susceptibility to pests and pathogens known to cause widespread tree mortality. Selected trees contain a mix of rapid, moderate, and slow growers differing in their shade tolerances (Table 1).

Trees were planted in October 2010. Planted trees were procured from Pinelands Nursery in Columbus, New Jersey, U.S.A. Trees were 3- to 5-year-old saplings measuring approximately $0.6-1.2 \mathrm{~m}$ in height, with root masses contained in either 1 or 2 gallon (approximately 3.79 or $7.58 \mathrm{~L}$, respectively) containers. Trees were planted with a hand-held mechanized post-hole digger in holes of appropriate size to house the tree roots (approximately $25 \mathrm{~cm}$ diameter and approximately $25 \mathrm{~cm}$ deep). Half of the 54 plots received compost and half were planted with shrubs ( 5 species, 41 plants per plot) in a crossed design with the compost amendments. Shrubs and herbs were planted at the same time as the trees, and were planted in holes large enough to accommodate root masses. The most abundant shrubs and herbs within each plot include shrubs Sambucas canadensis, Hamamelis virginiana, and Viburnum dentatum; and herbs Apocynum cannabinum, Asclepias syriaca, and Panicum virgatum. A full species list is included in Felson et al. (2013). Herbaceous plantings suffered significant dieback after the first year of planting, and subsequent colonization of the plots by incoming herbaceous vegetation made it difficult to parse out the difference between planted and non-planted herbs. As such, we refer to this treatment as "shrub" because it is these planted woody perennials that are driving the dynamics observed for this treatment.

\section{Site Preparation}

Full details outlining site preparation can be found in Oldfield et al. (2014). Briefly, the planting areas received extensive site preparation in advance of the tree and shrub plantings. Soils were weeded and roto-tilled to de-compact soil, allowing for soil loosening and removal of large debris to a depth of approximately $15 \mathrm{~cm}$. The compost treatment plots were then amended with compost at a rate of $2.5 \mathrm{~m}^{3}$ per $100 \mathrm{~m}^{2}$, incorporated to $15 \mathrm{~cm}$ depth. The commercial compost consisted of a blend of nutrient-rich biosolids and clean, ground wood chips. All research plots received a surficial layer $(5 \mathrm{~cm})$ of shredded hardwood mulch to minimize drought stress on the planted saplings.

\section{Tree Measures}

Approximately 10 months after trees were planted (August 2011), we conducted a field survey of the 24 centrally located trees in each research plot for a total of 1,296 trees. We recorded whether they were alive, dead, or missing and took measurements of their height and root collar diameter. Height was taken from soil level to the tip of the lead-stem. In instances where trees had multiple stems, we measured the tallest one. We recorded root collar diameter using calipers to measure the diameter of the main stem at soil level; note that trees were too small to measure diameter at breast height, and lateral branching

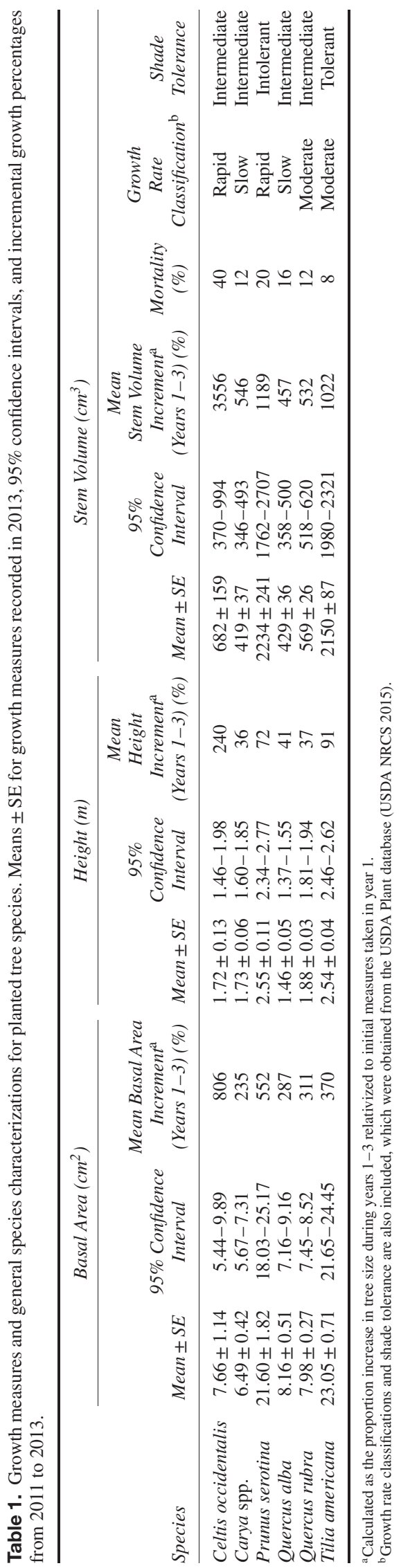


on some species prevented taking diameter measures $10 \mathrm{~cm}$ above ground level. Given the differing morphologies of the trees, root collar diameter provided a consistent measure across species to test for differences in growth, and it is often used as a measure to test for statistical differences in the growth of tree seedlings (Halter et al. 1993; Page-Dumroese et al. 1998). We repeated these assessments of height and diameter in August 2012 and August 2013. We used root collar diameter to calculate basal area on an individual tree basis, which was then summed across trees to determine total basal area per plot. To estimate stem biomass volume, we used the formula for a cone, using the height and root collar diameter measures (Magnussen \& Reed 2004). Like basal area, stem volume was recorded at the individual tree level and then summed to determine total stem volume at the plot level.

\section{Statistical Analyses}

We analyzed how plot treatments (composition, shrub, compost) affected survival and growth in tree diameter, height, and stem volume, both across research plots as a whole and also by species. For the mortality analyses, we used a generalized linear model with a binomial error distribution. For the growth analyses, we used a linear mixed model (LMM) approach to account for the unbalanced replication (see Site description and experimental design) and the non-independent spatial and temporal associations in our data. By specifying individual tree nested in plot as a random effect, our LMMs account for the possibility that plots paired by the shrub treatment (see Fig. 1B \& 1C) are more similar to each other than to other plots, and also account for the fact we had repeated measurements on the same units (i.e. the same tree in 2011, 2012, and 2013). Our approach is then conceptually equivalent to using nesting and repeated measures in ANOVA, and is now widely adopted in environmental science (Bolker et al. 2009; Bradford et al. 2012; Kramer et al. 2012), given the advantages it provides in model power and evaluation (see next paragraph). Plot treatments (composition, shrub, compost) and year $(1,2,3)$ were identified as fixed effects. We also tested for interactions between treatments and between treatments and year. We tested for treatment effects on the relative growth in basal area and stem volume (calculated as the proportion increase in growth during years 1-3 relativized to initial measures in year 1) at the species and plot level. We specified relative growth from year 1 to year 3 as the response variable with plot treatments identified as fixed effects and tree nested within plot as a random effect.

To select the best models for tree growth, we used the model with the lowest Akaike information criterion (AIC) score (Burnham et al. 2011). Variance inflation factors less than 5 indicated that collinearity was sufficiently low among predictor variables. The LMMs were all fit assuming a Gaussian error distribution. We used the "nlme" package in the "R" statistical program for our LMMs, and the summary function in the "LMERtest" package to estimate model coefficients and $p$ values.

\section{Results}

\section{Tree Survival}

After 3 years, a total of 180 of the 1,296 assessed trees were scored as either dead or missing. By year 3, more trees were recorded as missing versus dead (109 vs. 71). When trees were visibly dead, we scored them as such. In cases when we could not locate trees, we scored them as missing. Missing trees likely resulted from multiple factors, including vandalism, theft, fire, and severe herbivory. Six species plots had 1.6-times more dead and missing trees than two species plots $(p<0.001)$. Composted plots also had a higher degree of mortality $(17 \pm 1 \%)$ than non-composted plots $(11 \pm 1 \%)(p<0.01)$. Mortality increased across the 3 years from $1 \%$ in year 1 , to $6 \%$ in year 2 , to almost $14 \%$ in year 3 . Mortality varied among species, with Celtis occidentalis having the highest percent mortality after 3 years at $40 \%$ and Tilia americana having the lowest at $8 \%$ (Table 1). As tree size varied between species at the time of planting, we tested to see whether our first height measurement taken in 2011 was a significant predictor of tree mortality in 2012 and 2013. Tree height in 2011 did have a significant effect on 2012 survival $(p<0.05)$ for $C$. occidentalis, Carya spp., Quercus rubra, and T. americana; and a significant effect $(p<0.05)$ on 2013 mortality for C. occidentalis, Carya spp., and Quercus alba. Larger trees suffered less mortality than smaller trees for each of those species; however, it is difficult to determine the ultimate cause of mortality.

\section{Plot-Level Response}

For each research plot, we calculated total plot basal area, the mean height, and total plot stem volume to determine how treatments affected tree performance at the plot level. All metrics responded differently to plot treatments, although they consistently increased from year 1 to year 3, demonstrating that, overall, the trees were growing as opposed to dying or in decline (Table 2).

By year 3, total tree basal area per plot was $23 \%$ higher in composted versus non-composted plots $(p=0.031)$. Total tree basal area was also $13 \%$ higher in plots planted with shrubs $(p=0.01)$ and $7 \%$ higher in two species plots compared with six species plots ( $p=0.05$; see Fig. 2A). Relative growth in basal area increment (BAI) was calculated as the percent increase in growth from year 1 to year 3. Compost was the only treatment to have a significant effect on BAI $(p=0.003)$, with composted plots growing $69 \%$ faster compared with non-composted plots.

Species composition had a significant effect on tree height (Table 2). As with basal area, height was greater in two species plots with trees $10 \%$ taller than those in six species plots (Fig. 2B). The best-fit statistical model retained both a shrub-by-year interaction and a compost-by-year interaction, with those treatments having pronounced effects in year 3 but not years 1 and 2 (Tables $2 \&$ S1, Supporting Information). In year 3 , the measured height of trees was $8 \%$ higher in composted plots and $12 \%$ higher in plots planted with shrubs (Fig. 2B). 
Table 2. Coefficients and $p$ values for plot treatment effects on planted tree growth as measured as total basal area per plot, mean height, and total stem volume per plot of individual trees across 2011-2013. The negative coefficients for the main effect of compost for total basal area, height, and total stem volume are due to their interaction with year and cannot be interpreted alone, highlighting that the positive effects of compost grow over time. Coefficients and $p$ values are presented for each parameter. All treatments retained within the best-fit statistical model are presented, and statistically significant $(p<0.05)$ terms are shown in bold text.

\begin{tabular}{lrc}
\hline & Coefficient & $\mathrm{p}$ Value \\
\hline (A) Total basal area $\left(\mathrm{cm}^{2} / \mathrm{m}^{2}\right)$ & & \\
Intercept & 16.61 & 0.44 \\
Composition & -33.55 & 0.053 \\
Shrub & $\mathbf{2 4 . 1 6}$ & $\mathbf{0 . 0 1 0}$ \\
Compost & $\mathbf{6 1 . 6 8}$ & $\mathbf{0 . 0 3 1}$ \\
Year & $\mathbf{8 2 . 7 6}$ & $<\mathbf{0 . 0 0 1}$ \\
Compost $\times$ Year & $\mathbf{4 4 . 4 3}$ & $<\mathbf{0 . 0 0 1}$ \\
(B) Height $(\mathrm{m})$ & & \\
Intercept & 1.18 & $<0.001$ \\
Composition & $\mathbf{- 0 . 2 1}$ & $\mathbf{0 . 0 1}$ \\
Shrub & -0.16 & 0.081 \\
Compost & -0.19 & 0.12 \\
Year & $\mathbf{0 . 2 7}$ & $<\mathbf{0 . 0 0 1}$ \\
Shrub $\times$ Compost & 0.13 & 0.06 \\
Shrub $\times$ Year & $\mathbf{0 . 1 1}$ & $<\mathbf{0 . 0 1}$ \\
Compost $\times$ Year & $\mathbf{0 . 1 1}$ & $<\mathbf{0 . 0 1}$ \\
C) Total stem volume $\left(\mathrm{cm}^{3} / \mathrm{m}^{2}\right)$ & & \\
Intercept & -3748.3 & 0.13 \\
Shrub & -4412.6 & 0.098 \\
Compost & $\mathbf{6 9 3 9 . 1}$ & $\mathbf{0 . 0 2 6}$ \\
Year & $\mathbf{7 7 0 3 . 4}$ & $\mathbf{0 . 0 0 1}$ \\
Shrub $\times$ Compost & $\mathbf{4 0 6 9 . 6}$ & $\mathbf{0 . 0 3 2}$ \\
Shrub $\times$ Year & $\mathbf{2 6 5 3}$ & $\mathbf{0 . 0 2 3}$ \\
Compost $\times$ Year & $\mathbf{4 1 8 3 . 4}$ & $\mathbf{0 . 0 0 1}$ \\
\hline
\end{tabular}

Total tree stem volume per plot and growth rate were significantly affected by compost with an interaction with year $(p<0.001)$. Stem volume growth rate was $73 \%$ greater in composted plots over the course of 3 years. Consequently, total stem volume on composted plots was $27 \%$ higher than non-composted plots. The best-fit statistical model for total stem volume per plot also retained shrubs as a main effect, a compost-by-shrub interaction, and a shrub-by-year interaction. The presence of shrubs led to significantly more tree stem volume per plot $(p=0.02)$, with shrub treatment plots containing $24 \%$ more stem volume (of the trees) than plots without (Fig. 3).

\section{Species Response}

All six of the planted tree species grew markedly in all recorded measures across each successive growing season (see Table $3 \&$ Tables S2 \& S4). We could assess the influence of only two treatments, shrubs and compost, for four of the tree species, whereas for the other two species ( $Q$. rubra and T. americana), we could also assess the effects of the species composition treatment because they were present in both the two and the six species plots (see Fig. 1B \& 1C).

Compost had a positive effect on root collar growth with measures of diameter being 15-30\% greater (depending on
(A) Two Species Six Species
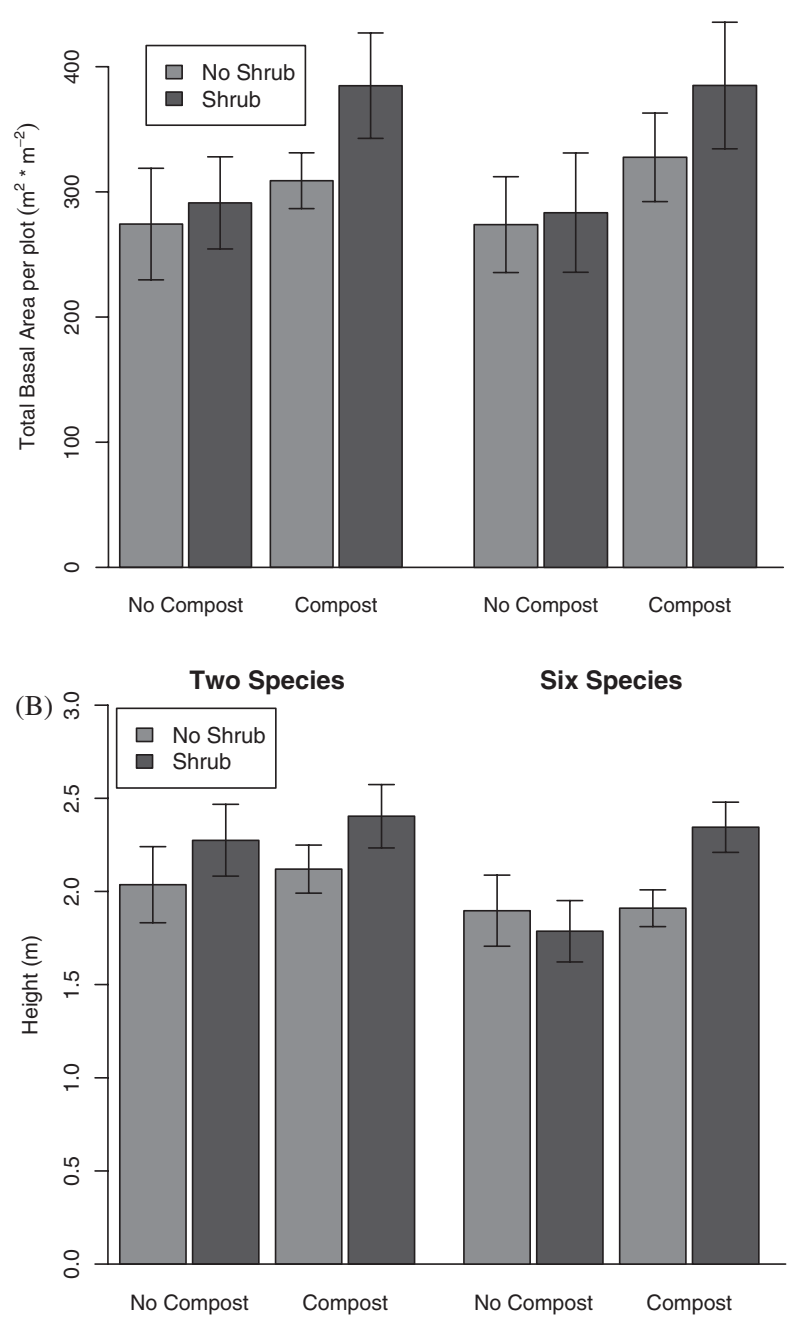

Figure 2. Treatment effects on a per plot basis for (A) basal area and (B) height of main stem. We calculated the total basal area per plot and the mean tree height across the research plots to assess which plot treatments were driving differences in plot-level growth. Error bars represent \pm SE. The number of replicates are as follows: two species/no shrubs/no compost, $n=9$; two species/no shrubs/compost, $n=5$; two species/shrubs/no compost, $n=9$; two species/shrubs/compost, $n=5$; six species/no shrubs/no compost, $n=5$; six species/no shrubs/compost, $n=8$; six species/shrubs/no compost, $n=5$; six species/shrubs/compost, $n=8$.

The graphs include measures only from year 3 , and include all plot treatments as each was retained in the best-fit statistical models. See Table 2 for treatment coefficients and $p$ values.

the species) for trees in composted plots. Models for all six species retained a significant compost-by-year interaction, with diameters in year 3 for each species markedly greater in compost versus no-compost plots, with minimal differences in years 1 and 2 (see Tables S2 \& S4). Tilia americana but not Q. rubra retained a significant species composition by year interaction, with $T$. americana in six species plots showing greater girth in root collar diameter than those in two species plots, particularly in year $3(6.11 \pm 0.17 \mathrm{~cm}$ vs. $4.86 \pm 0.085 \mathrm{~cm}$, respectively; see Fig. 4A). 
Table 3. Means \pm SE for each measure of growth for species in six species composition plots for 2013 (for 2011 and 2012 values, see Table S4). Values for 2013 capture the effect that plot treatments are having on individual species' growth for the latest measurement year. Significant treatment effects $(p<0.05)$ are shown in bold text for the differences between plots with and without either shrubs or compost. See Figures 4-6 and Table S2 for size measures for Quercus rubra and Tilia americana.

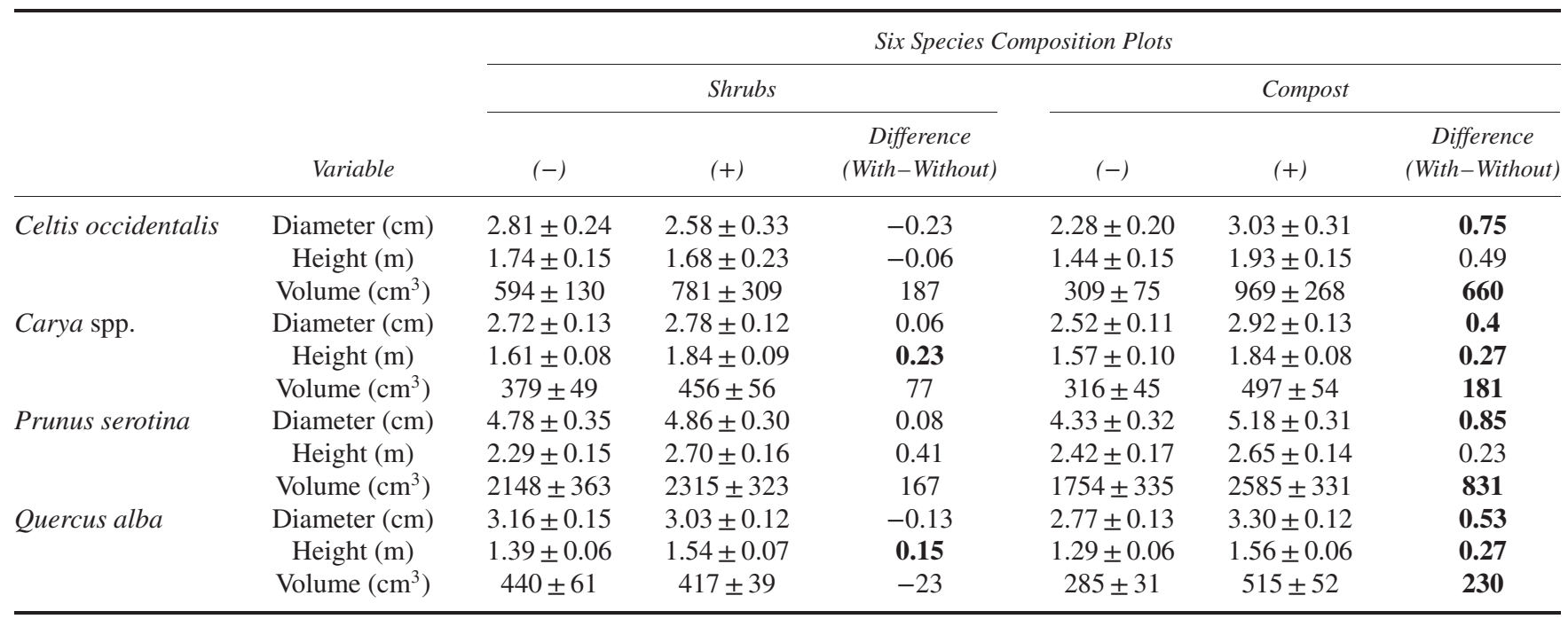

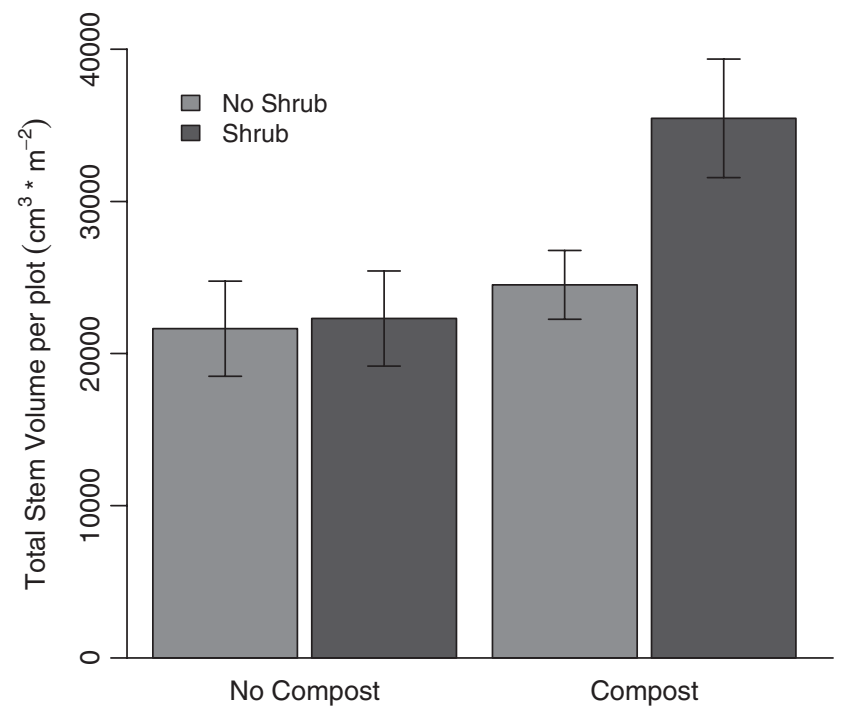

Figure 3. Treatment effects per plot for total stem volume. The effects of the interaction between the shrub and compost treatment are clearly apparent, with composted plots containing shrubs having significantly more stem volume compared with the other treatments. Error bars represent \pm SE. The number of replicates are as follows: no shrub/no compost, $n=14$; no shrub/compost, $n=13$; shrub/no compost, $n=14$; shrub/compost, $n=13$. See Table 2 for treatment coefficients and $p$ values.

Basal area responses mapped onto those for root collar diameter growth (as it was calculated from each tree's root collar diameter). Yet only compost effects were apparent for BAI for each species from year 1 to year 3. Composted plots had higher growth in basal area than non-composted plots for all species, with significant differences $(p<.05)$ for $C$. occidentalis, Carya spp., and $T$. americana; compost had a marginally significant effect on $Q$. alba $(p=0.06)$ (Tables $4 \& 5)$.
Height responses to plot treatments were also fairly consistent in the sign of the effect across species, with significant or marginally significant shrub-by-year interactions retained in models for five of the six species (Carya spp., Prunus serotina, Q. alba, Q. rubra, and T. americana). All of these species exhibited greater height in plots planted with shrubs versus plots without, with differences most pronounced in year 3 (Tables S2 \& S4). For instance, the height of Q. rubra was $14 \%$ greater in shrub versus no shrub plots by year 3 (Fig. 5A). Tilia americana also retained a compost-by-shrub interaction, indicating that trees were tallest in compost-amended plots planted with shrubs and that this response would not have been predicted from either the compost or shrub treatments alone (Fig. 4B). Notably, compost effects on tree height were less consistent across species than the effects of compost on root collar diameter and basal area, where there were always compost-by-year interactions. For example, for three species (C. occidentalis, Q. rubra, and P. serotina), there were no significant compost or compost-by-year effects on height (Tables S3 \& S5).

Stem volume, like basal area, responded fairly consistently and positively to compost among species, with five of the six species showing a significant compost-by-year interaction (for all five species, $p<0.05$ ). Quercus rubra was the only species that did not retain a compost-by-year interaction in its best-fit statistical model for growth in stem volume. However, the best model did retain a compost-by-shrub interaction, with the positive effect of shrubs on stem volume manifesting only in composted plots (Fig. 5B). Tilia americana retained a significant year interaction for each of the three treatments (Table S3), where treatment effects on stem volume were most pronounced in year 3 (Table S2), with six species, compost amendments, and shrub presence all equating to greater stem volume in 2013 (Fig. 6). The best-fit models for relative growth 
(A)
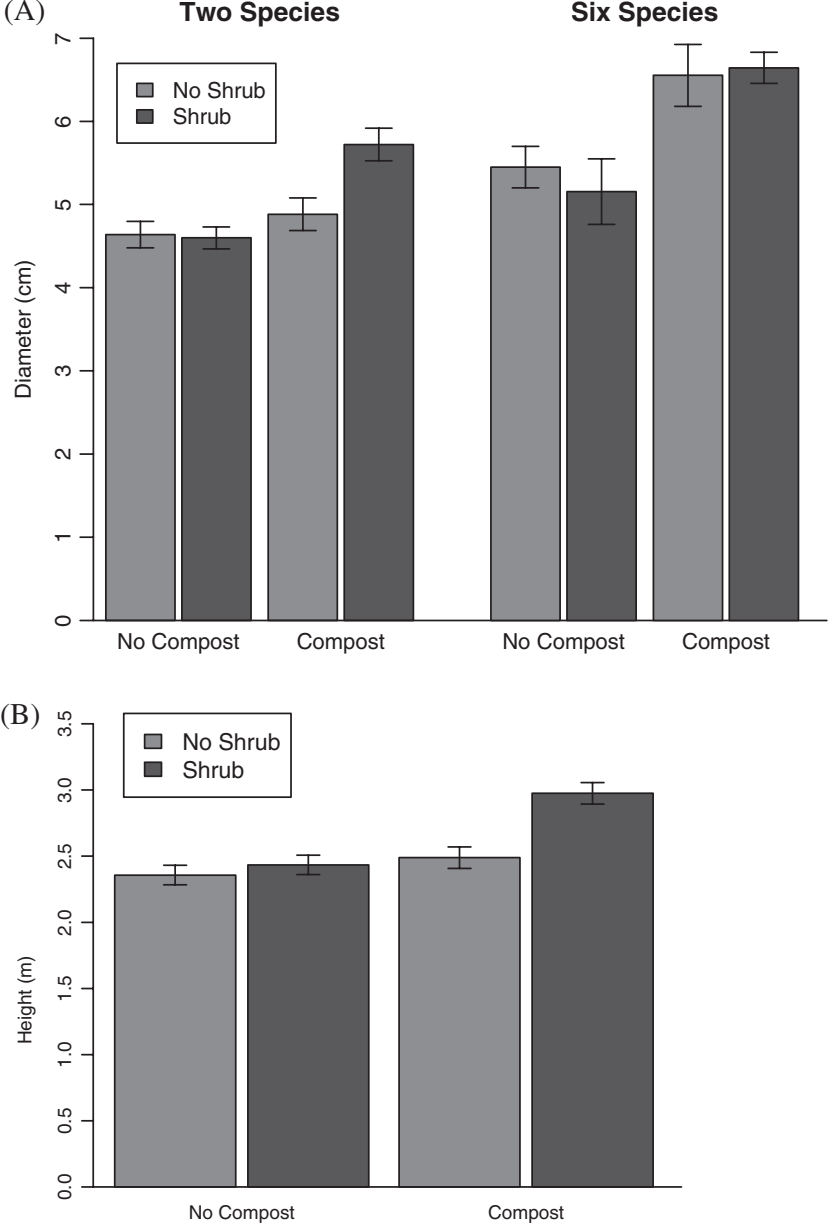

Figure 4. Treatment effects for Tilia americana on (A) diameter and (B) height. For both root collar diameter and height, the best-fit statistical models retained treatment-by-year interactions, and so the results for year 3 only are presented in these graphs, as that is the only year that exhibits statistically different results in measured parameters between treatments. Error bars represent \pm SE. For (A) the number of replicates are as follows: two species/no shrubs/no compost, $n=108$; two species/no shrubs/compost, $n=60$; two species/shrubs/no compost, $n=108$; two species/shrubs/compost, $n=60$; six species/no shrubs/no compost, $n=20$; six species/no shrubs/compost, $n=32$ six species/shrubs/no compost, $n=20$; six species/shrubs/compost, $n=32$. For (B) the number of replicates are as follows: no shrub/no compost, $n=128$; no shrub/compost, $n=92$; shrub/no compost, $n=128$; shrub/compost, $n=92$. See Table S3 for treatment coefficients and $p$ values.

in stem volume from year 1 to year 3 all retained compost, with it having a significant effect $(p \leq 0.05)$ on $C$. occidentalis, Carya spp., and $Q$. alba. Compost had a marginally significant effect $(p=0.06)$ on $T$. americana's relative growth in volume (Table 4).

\section{Discussion}

Growth performance of juvenile trees is a critical determinant of the viability and sustainability of urban afforestation initiatives (Ruiz-Jaen \& Aide 2006), yet data on planted juvenile survival and growth are sparse. We show that six native species respond relatively consistently to plot treatments, yet individual species performance varies markedly. Tree species composition explained differences in the basal area and height of trees at the plot level, with two species plots having taller trees on average and greater basal area. This result appears counter-intuitive given expected positive effects of plant diversity on ecosystem functioning (Isbell et al. 2011), but in our study this effect appears to be driven by a single high-performing species. Specifically, half of the trees in two species plots were T. americana. This species' mean diameter and height in year 3 were substantially greater than those of the other planted species, except Prunus serotina, which is of similar size (Table 1). Differences in individual species performance also appear to account for the fact that six species plots had greater rates of mortality, owing to the high incidence of mortality (40\% by year 3) of Celtis occidentalis (Table 1). Therefore, tree species composition effects (i.e. 2 vs. 6 species plots) at the plot level appear driven more by the characteristics of individual species in the different treatment levels, rather than the composition treatment influencing the strength of positive or negative interactions among tree individuals.

There was evidence of species composition treatment effects on the strength of interactions when individual species responses were considered. For example, despite explaining the greater growth of trees within the two species treatment at the plot level, T. americana had greater individual diameter and volume in the six species plots by year 3. In contrast, Q. rubra, the second species in the two species plots, had greater volume in the two versus six species plots, but this effect was not statistically significant despite being retained in the best-fit model. The effects of the species composition treatment on these two species point to influences of competition and/or facilitation between these two species. It is difficult to disentangle these effects to determine direct causation, but such interactions are considered key in shaping how mixtures perform (Forrester et al. 2006; Piotto 2008). For example, it is possible that $T$. americana grew less in the two species plots because the large individual size of this species generated intra-specific competition that was more pronounced than the inter-specific competition with the smaller stature species in the six species plots. Not mutually exclusive is the possibility that $Q$. rubra could have a more suppressive (or less facilitative) effect on the growth of $T$. americana than other species in the experiment, although the mechanism for this is unclear. Our experiment is not designed to tease out these mechanisms as we lack an experimental control that would help elucidate these possible effects. Regardless, our results suggest that planting $T$. americana in more diverse mixtures improves its performance.

The presence of shrubs influenced the performance of the tree species, again suggesting that the treatments altered interactions among planted individuals. Shrub presence was associated with greater height of tree species, except for $C$. occidentalis. For the other five species, a shrub-by-year interaction was retained in all of the best-fit statistical models (see Tables S3 \& S5), reflecting the fact that the influence of shrubs was most pronounced by 
Table 4. Means \pm SE of relative growth measures for species in six species plots in 2013. Significant treatment effects $(p<0.05)$ are shown in bold text for the differences between plots with and without either shrubs or compost. Relative growth measures are calculated as the proportion increase in tree size during years $1-3$.

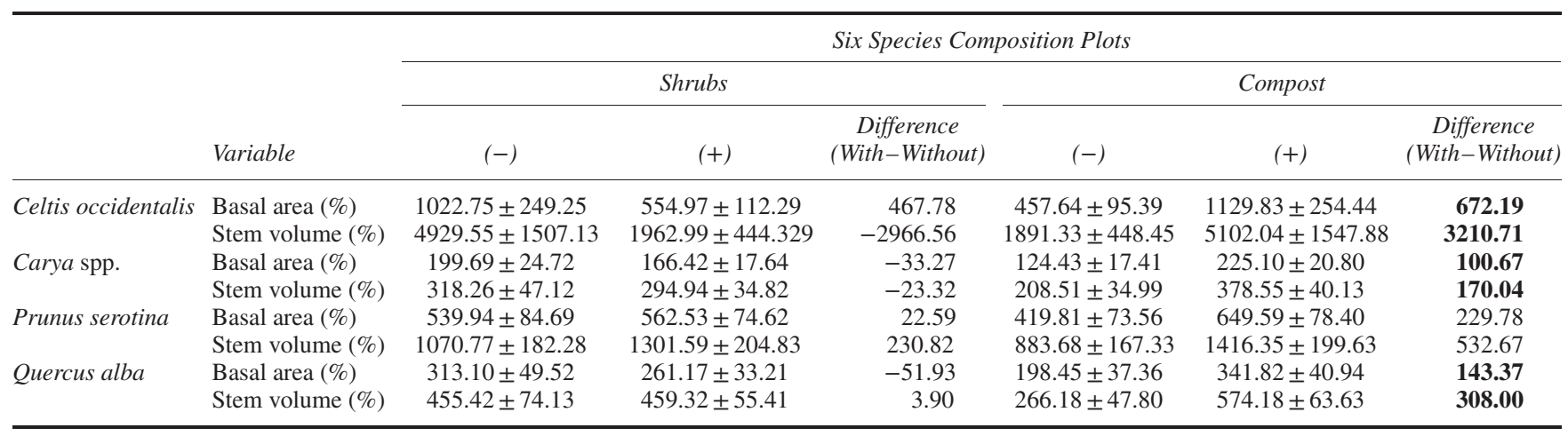

year 3. Shrub presence impacted the performance of planted trees at the plot level as well. The presence of shrubs led to greater total basal area and total stem volume per plot as well as greater height of planted trees. These results are likely the result of either competition and/or facilitation between the planted trees and shrubs. Competition has long been recognized as an interaction structuring plant communities (Hutchinson 1957), and in our research plots those including shrubs had higher stocking densities than those without. Whereas height is generally considered insensitive to competition (Lanner 1985), the narrow spacing of the planted trees coupled with the inclusion of shrubs may reflect more intense light competition, and trees in non-urban forest stands tend to reach greater heights when planted at narrow spacings (Oliver \& Larson 1996; Piotto 2008). Supporting this inference, the planted Sambucas canadensis shrubs were at least as tall as and sometimes overtopped the planted trees. This shrub can colonize by root suckers, and may be driving planted trees to put more energy into height acquisition versus diameter growth. Alternatively, the $S$. canadensis and other planted shrubs may be facilitating the growth of the planted trees by alleviating direct effects of high light on the saplings, creating beneficial micro-climates of soil temperature and moisture, and/or decreasing negative effects of aggressive exotic plants that might otherwise compete for space. These effects require further exploration to identify the responsible mechanisms, so they might be replicated in future restoration efforts.

Carbon sequestration is a priority for urban afforestation initiatives (Poudyal et al. 2011; Raciti et al. 2012). As such, we calculated stem volume using height and diameter to get an estimation of biomass accumulation. Although variation in wood density across and within species influences carbon storage (Fearnside 1997), estimates of biomass volume can help identify species and land management strategies that might facilitate high carbon capture. Compost had a positive effect on basal area and tree volume at the plot level and on all of the species, supporting the idea that most urban soils have low tilth and that compost amendments are an effective remediation strategy (Cogger 2005; Pavao-Zuckerman 2008). Although all species responded positively to compost, $P$. serotina and
T. americana had three to five times the amount of biomass volume than the other four tree species, highlighting that species choice will be important for achieving the objectives of urban afforestation initiatives.

Compost effects on the planted trees did not manifest until the third growing season, though the biological, physical, and chemical properties of the soils at our study site responded immediately to the addition of compost. The application of compost increased water-holding capacity and microbial biomass, and led to more acidic (vs. neutral) $\mathrm{pH}$ values, creating what would be considered more favorable conditions for growth of the planted trees (Oldfield et al. 2014). The delayed effects of compost on tree growth may point to the slow-release nature of nutrients in compost amendments. As compost is pre-digested by microbes, the release of nutrients such as nitrogen relies on decomposition, meaning that nutrients become available at much slower rates than with mineral fertilizer, resulting in productivity gains that manifest over longer timescales (Ryals \& Silver 2013). This delayed response might have also resulted from the trees overcoming transplant shock and putting more resources into roots versus aboveground biomass in years 1 and 2. Whatever the explanation, from a management perspective the delayed response to compost is an important finding. Exploring compost effects on the trees in only the first and second growing seasons might have led to the conclusion that compost amendments were an expensive but ineffective strategy. For our study, compost amendment cost approximately U.S.\$75,000 for the research plots. Our results demonstrate that tree dynamics are unlikely to be inferred from short (1-2 years) time frames, emphasizing the need of critical research for longer-term urban afforestation studies (Oldfield et al. 2013). Reconciling the longer time frames of mature forest development with more immediate management decisions is crucial in urban forestry. Land managers need to identify effective strategies in the short term that improve tree growth, helping ensure the success of urban tree planting initiatives in the long term.

Despite the lack of natural analogues, our data generally support the use of non-urban classifications (e.g. growth rate classifications; Table 1) for species performance expectations in urban systems. For example, both Carya and Quercus species, 
which are classified as slow to moderate growers (USDA NRCS 2015), exhibited much lower growth rates in height, basal area, and stem volume when compared with the other planted species. Celtis occidentalis and $P$. serotina, both classified as rapid growers (USDA NRCS 2015), had the largest relative growth rates in basal area, height, and stem volume. However, choices based on growth rate alone must also consider whether planted individuals will survive. Overall, mortality after 3 years for $C$. occidentalis was particularly high (40\%), but quite low (12\%) for the two slow-growing species. High mortality in the six species plots could then create gaps that might be filled by co-occurring planted natives such as T. americana or aggressive invaders taking advantage of available resources. Gap creation could then be a positive or negative, respectively, in terms of the overall aim to establish native, urban forests.

There were some surprises in species performance. Specifically, the fact that $P$. serotina and T. americana, the two species that grew largest, were approximately equal in size by the third growing season. We did expect high rates of growth for $P$. serotina, given its classification as a rapid grower and its shade intolerance (USDA NRCS 2015); however, T. americana is classified as a moderate grower and shade tolerant (USDA NRCS 2015). This discrepancy in classification and performance might be explained by the fact $T$. americana is capable of good growth on more neutral pH soils (Burns et al. 1990), as are found in many urban systems, including at our site (Oldfield et al. 2014). Data from our 2013 field survey also indicate that these two species are the only planted species already setting fruit, albeit as a small proportion of individuals ( $12 \%$ for $P$. serotina and $1.2 \%$ for $T$. americana). A key element of urban afforestation initiatives is enhancing local biodiversity, and fruit-setting will likely attract honeybees, birds, and small mammals to newly planted urban forests (Robinson \& Handel 2000). In terms of achieving canopy closure, aboveground carbon storage, and enhancing biodiversity - key objectives of urban tree planting initiatives - planting P. serotina and T. americana would appear to be the fastest way to achieve these objectives in their native regions.

Urban afforestation initiatives have multiple goals (e.g. carbon capture, improving air quality, storm-water mitigation) linked to improving the health of the urban environment. However, there is a distinct paucity of data to inform the choice of tree species and afforestation strategies that will lead to the formation of the established, mature urban forest upon which the multiple goals depend. This study helps redress this lack of information for tree species native to the eastern United States. Although we present data for the performance of juvenile trees across only the first three growing seasons, distinct species differences and treatment effects emerge. Among these, it is notable that the positive effects of compost amendment take 3 years to become apparent and that shrub presence generally promotes growth in the height of planted trees. It will be many years before this developing forest matures, but we show that our results on sapling performance can help meet the immediate need for data to inform the species choice and management strategies of the rapidly growing number of afforestation projects in cities across the globe. 
(A)

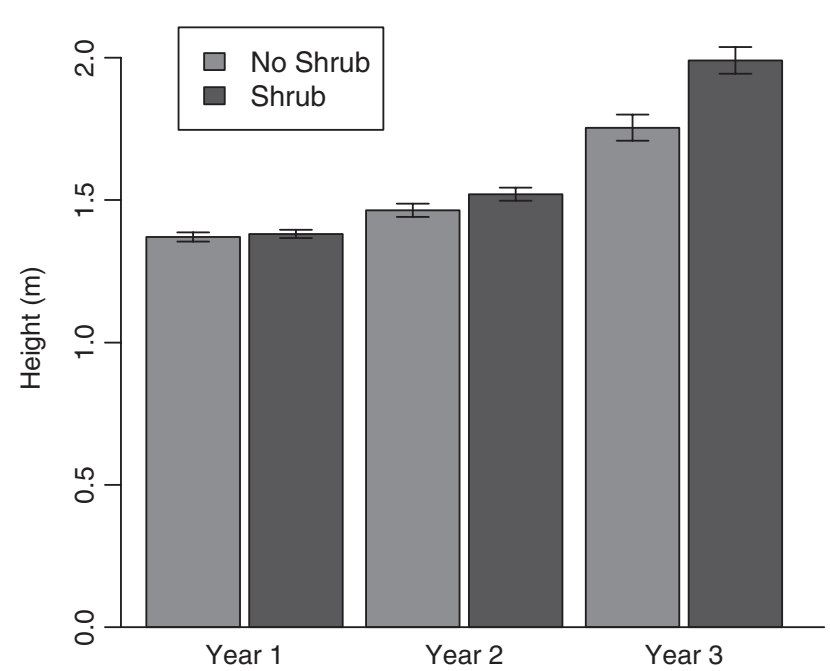

(B)

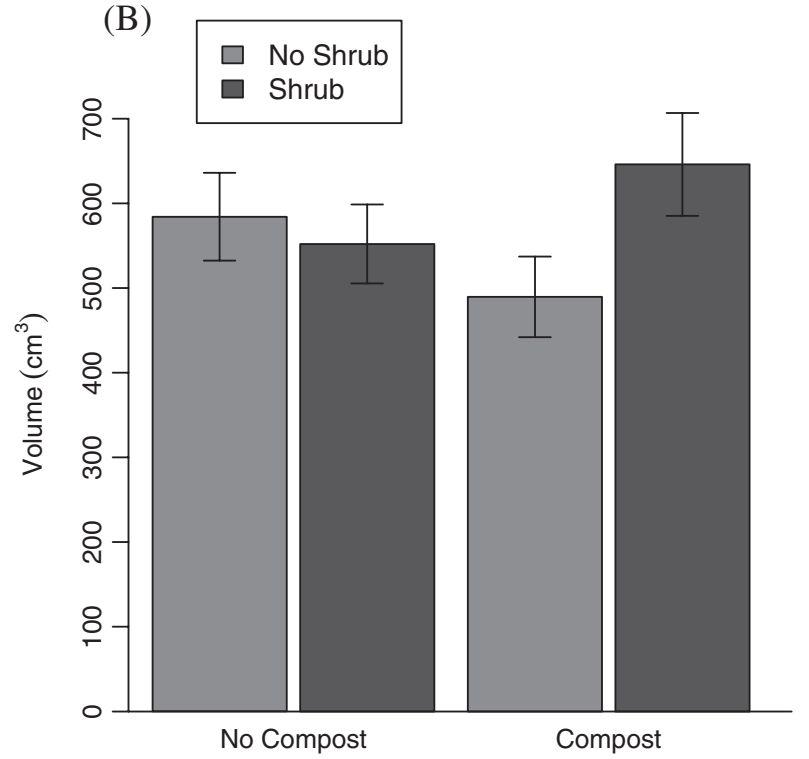

Figure 5. Treatment effects on the (A) height and (B) stem volume of Quercus rubra. The interaction between shrub and year for height is clearly indicated, with significant differences occurring only in year 3; for stem volume (B), we present data only from year 3. Error bars represent \pm SE. For (A) the number of replicates are as follows: no shrub, $n=220$; shrub, $n=220$. For (B) the number of replicates are as follows: the number of replicates are as follows: no shrub/no compost, $n=128$; no shrub/compost, $n=92$; shrub/no compost, $n=128$; shrub/compost, $n=92$. See Table S3 for treatment coefficients and $p$ values.

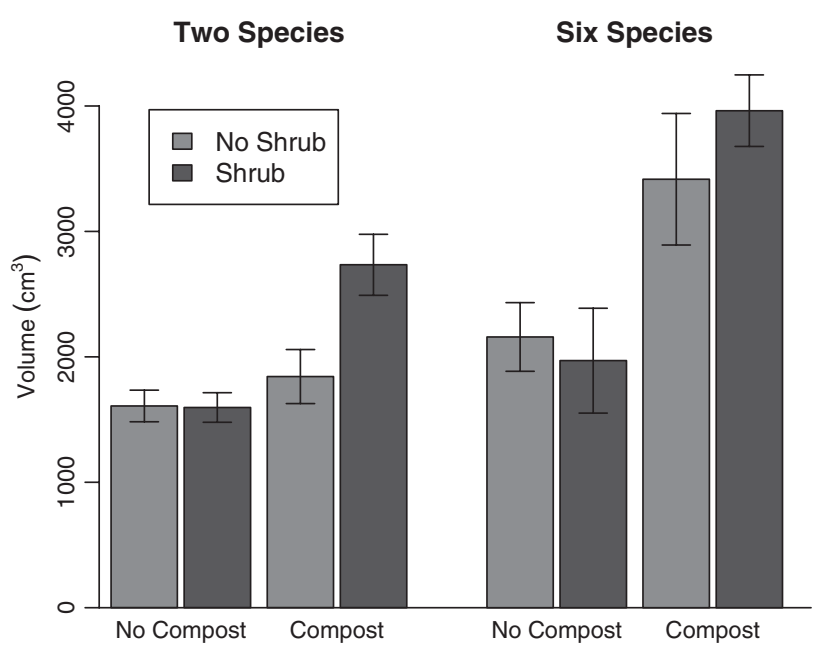

Figure 6. Treatment effects on the stem volume of Tilia americana. Presented are results from year 3. The best-fit statistical models retained all treatments, as well as significant interactions between them, including composition $\times$ compost and shrub $\times$ compost. Error bars represent \pm SE. See Figure $4 \mathrm{~A}$ for number for replicates per treatment. See Table S3 for treatment coefficients and $p$ values.

\section{Acknowledgments}

This work was funded in part by the Global Institute of Sustainable Forestry and the Yale School of Forestry and Environmental Studies. We thank the New York City Department of Parks \& Recreation for constructing the study site and facilitating the research and the New York City Urban Field Station for logistical support.

\section{LITERATURE CITED}

Bolker BM, Brooks ME, Clark CJ, Geange SW, Poulsen JR, Stevens MHH, White JSS (2009) Generalized linear mixed models: a practical guide for ecology and evolution. Trends in Ecology \& Evolution 24:127-135

Brack CL (2002) Pollution mitigation and carbon sequestration by an urban forest. Environmental Pollution 116:S195-S200

Bradford MA, Wood SA, Maestre FT, Reynolds JF, Warren RJ (2012) Contingency in ecosystem but not plant community response to multiple global change factors. New Phytologist 196:462-471

Burnham KP, Anderson DR, Huyvaert KP (2011) AIC model selection and multimodel inference in behavioral ecology: some background, observations, and comparisons. Behavioral Ecology and Sociobiology 65:23-35

Burns RM, Honkala BH, tech. coords (1990) Silvics of North America: 1. Conifers; 2. Hardwoods. Agriculture Handbook 654, vol. 2. USDA Forest Service, Washington, D.C.

Cogger CG (2005) Potential compost benefits for restoration of soils disturbed by urban development. Compost Science and Utilization 13:243-251

Fearnside PM (1997) Wood density for estimating forest biomass in Brazilian Amazonia. Forest Ecology and Management 90:59-87

Felson AJ, Oldfield EE, Bradford MA (2013) Involving ecologists in shaping large-scale green infrastructure projects. Bioscience 63:882-890

Forrester DI, Bauhus J, Cowie AL, Vanclay JK (2006) Mixed-species plantations of Eucalyptus with nitrogen-fixing trees: a review. Forest Ecology and Management 233:211-230

Gaffin SR, Rosenzweig C, Kong AYY (2012) Adapting to climate change through urban green infrastructure. Nature Climate Change 2:704

Halter MR, Chanway CP, Harper GJ (1993) Growth reduction and root deformation of containerized lodgepole pine saplings 11 years after planting. Forest Ecology and Management 56:131-146

Hutchinson GE (1957) Concluding remarks. Cold Spring Harbor Symposia on Quantitative Biology 22:415-427

Isbell F, Calcagno V, Hector A, Connolly J, Harpole WS, Reich PB, et al. (2011) High plant diversity is needed to maintain ecosystem services. Nature 477:199-202

Kowarik I (2011) Novel urban ecosystems, biodiversity, and conservation. Environmental Pollution 159:1974-1983 
Kramer TD, Warren I, Robert J, Tang Y, Bradford MA (2012) Grass invasions across a regional gradient are associated with declines in belowground carbon pools. Ecosystems 15:1271-1282

Lanner RM (1985) On the insensitivity of height growth to spacing. Forest Ecology and Management 13:143-148

Magnussen S, Reed D (2004) Modelling for estimation and monitoring. FAO-IUFRO

McPherson EG, Nowak D, Heisler G, Grimmond S, Souch C, Grant R, Rowntree R (1997) Quantifying urban forest structure, function, and value: the Chicago Urban Forest Climate Project. Urban Ecosystems 1: 49-61

McPherson G, Simpson JR, Peper PJ, Maco SE, Xiao QF (2005) Municipal forest benefits and costs in five U.S. cities. Journal of Forestry 103: $411-416$

Nowak DJ (2006) Institutionalizing urban forestry as a "biotechnology" to improve environmental quality. Urban Forestry \& Urban Greening 5:93-100

Nowak DJ (2012) Contrasting natural regeneration and tree planting in fourteen North American cities. Urban Forestry \& Urban Greening 11: 374-382

Nowak DJ, Crane DE, Dwyer JF (2002) Compensatory value of urban trees in the United States. Journal of Arboriculture 28:194-199

Nowak DJ, Noble MH, Sisinni SM, Dwyer JF (2001) People and trees: assessing the U.S. urban forest resource. Journal of Forestry 99:37-42

NRCS (2009) Soil Survey of Kissena Corridor Park, Queens, NY. NRCS, Lincoln, Nebraska

Oldfield EE, Felson AJ, Wood SA, Hallett RA, Strickland MS, Bradford MA (2014) Positive effects of afforestation efforts on the health of urban soils. Forest Ecology and Management 313:266-273

Oldfield EE, Warren RJ, Felson AJ, Bradford MA (2013) FORUM: challenges and future directions in urban afforestation. Journal of Applied Ecology 50:1169-1177

Oliver CD, Larson BC (1996) Forest stand dynamics. John Wiley \& Sons, Inc, New York, New York

Overdyck E, Clarkson BD (2012) Seed rain and soil seed banks limit native regeneration within urban forest restoration plantings in Hamilton City, New Zealand. New Zealand Journal of Ecology 36: $177-190$

Page-Dumroese DS, Harvey AE, Jurgensen MF, Amaranthus MP (1998) Impacts of soil compaction and tree stump removal on soil properties and outplanted seedlings in northern Idaho, U.S.A. Canadian Journal of Soil Science 78:29-34

Pataki DE, Carreiro MM, Cherrier J, Grulke NE, Jennings V, Pincetl S, Pouyat RV, Whitlow TH, Zipperer WC (2011) Coupling biogeochemical cycles in urban environments: ecosystem services, green solutions, and misconceptions. Frontiers in Ecology and the Environment 9:27-36

Pavao-Zuckerman MA (2008) The nature of urban soils and their role in ecological restoration in cities. Restoration Ecology 16:642-649
Piotto D (2008) A meta-analysis comparing tree growth in monocultures and mixed plantations. Forest Ecology and Management 255: $781-786$

Poudyal NC, Siry JP, Bowker JM (2011) Quality of urban forest carbon credits. Urban Forestry \& Urban Greening 10:223-230

Raciti SM, Fahey TJ, Thomas RQ, Woodbury PB, Driscoll CT, Carranti FJ, et al. (2012) Local-scale carbon budgets and mitigation opportunities for the northeastern United States. Bioscience 62:23-38

Rawlinson H, Dickinson N, Nolan P, Putwain P (2004) Woodland establishment on closed old-style landfill sites in NW England. Forest Ecology and Management 202:265-280

Robinson GR, Handel SN (2000) Directing spatial patterns of recruitment during an experimental urban woodland reclamation. Ecological Applications 10:174-188

Ruiz-Jaen MC, Aide TM (2006) An integrated approach for measuring urban forest restoration success. Urban Forestry \& Urban Greening 4:55-68

Ryals R, Silver WL (2013) Effects of organic matter amendments on net primary productivity and greenhouse gas emissions in annual grasslands. Ecological Applications 23:46-59

Sullivan JJ, Meurk C, Whaley KJ, Simcock R (2009) Restoring native ecosystems in urban Auckland: urban soils, isolation, and weeds as impediments to forest establishment. New Zealand Journal of Ecology 33:60-71

Troxel B, Piana M, Ashton MS, Murphy-Dunning C (2013) Relationships between bole and crown size for young urban trees in the northeastern U.S.A. Urban Forestry \& Urban Greening 12:144-153

USDA NRCS (2015) The PLANTS database. National Plant Data Team, Greensboro, North Carolina. http://plants.usda.gov (accessed 14 Jan 2015)

Vandermeer J (1989) Ecology of intercropping. Cambridge University Press, Cambridge, United Kingdom

\section{Supporting Information}

The following information may be found in the online version of this article:

Table S1. Means \pm SE for total basal area per plot, mean height per plot, and total stem volume per plot for each treatment.

Table S2. Means \pm SE for individual tree diameter, height, and stem volume for each treatment for (A) Quercus rubra and (B) Tilia americana.

Table S3. Coefficients and $p$ values retained in the best-fit statistical models for treatment effects on the growth in diameter, height, and stem volume for (A) Quercus rubra and (B) Tilia Americana. Significant treatment effects $(p<0.05)$ are shown in bold text.

Table S4. Means \pm SE for individual tree diameter, height, and stem volume for each treatment for (A) Celtis occidentalis, (B) Carya spp., (C) Prunus serotina, and (D) Quercus alba.

Table S5. Coefficients and $p$ values retained in the best-fit statistical models for treatment effects on the growth in diameter, height, and volume for (A) Celtis occidentalis, (B) Carya spp., (C) Prunus serotina, and (D) Quercus alba. Significant treatment effects $(p<0.05)$ are shown in bold text.

Received: 23 September, 2014; First decision: 22 November, 2014; Revised: 23 April, 2015; Accepted: 23 April, 2015; First published online: 29 May, 2015 
Table S1: Means $\pm \mathrm{SE}^{1}$ for total basal area per plot, mean height per plot, and total stem volume per plot for each treatment.

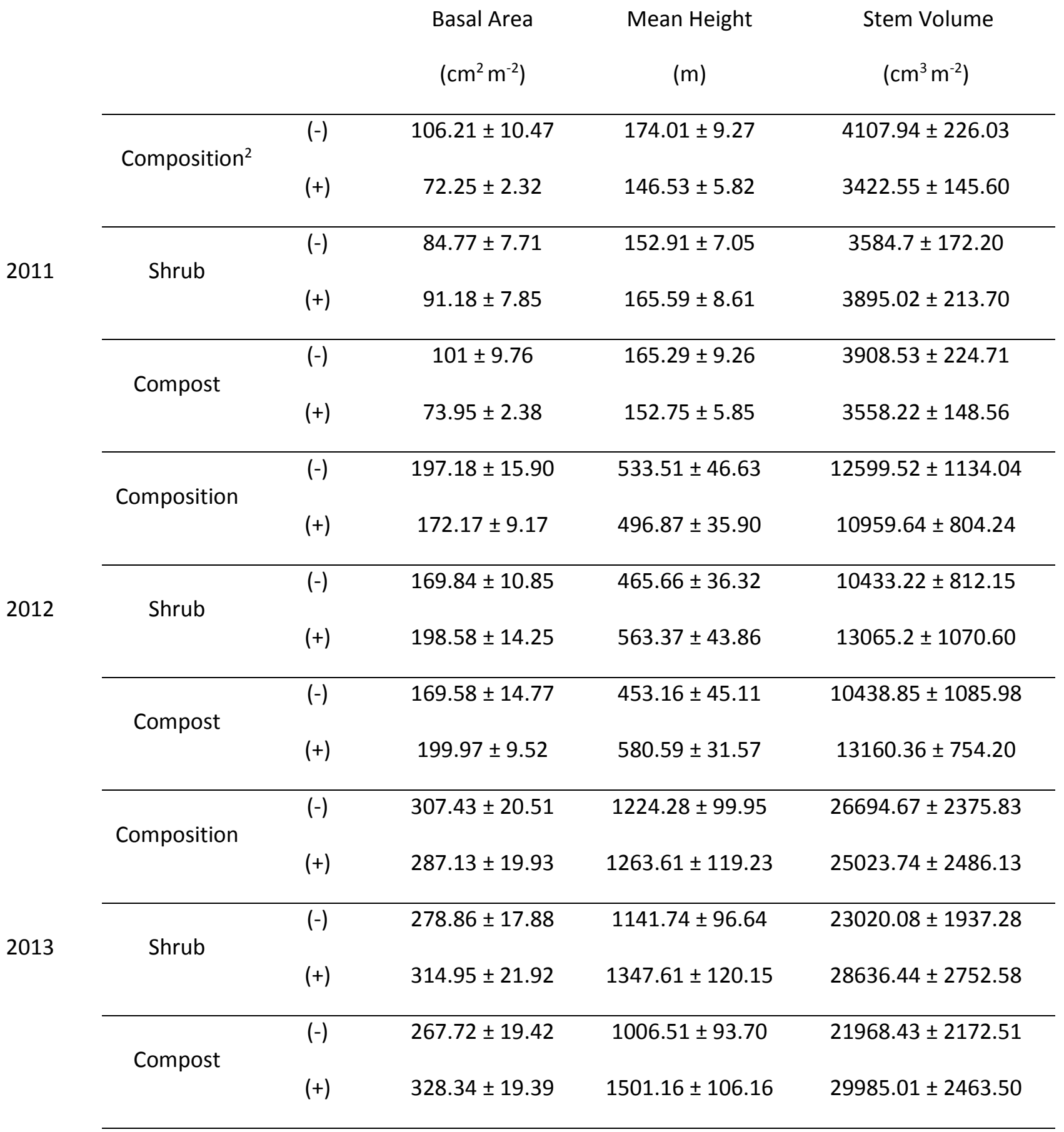

\footnotetext{
${ }^{1}$ The number of replicates are as follows: two species composition, $n=26$; six species composition, $n$ = 28; no shrubs, $n=27$; shrubs, $n=27$; no compost, $n=28$; compost, $n=26$.

${ }^{2}$ For the composition treatment, (-) indicates two species plots, (+) indicates six species plots.
} 

Table S2: Means $\pm \mathrm{SE}^{1}$ for individual tree diameter, height, and stem volume for each treatment for (a) Quercus rubra and (b) Tilia americana

a) Quercus rubra

2011

2013

b) Tilia americana
Diameter $(\mathrm{cm}) \quad$ Height $(\mathrm{m}) \quad$ Volume $\left(\mathrm{cm}^{3}\right)$

\begin{tabular}{cllll}
\hline Composition $^{2}$ & $(-)$ & $1.59 \pm 0.02$ & $1.39 \pm 0.01$ & $99 \pm 3$ \\
& $(+)$ & $1.55 \pm 0.03$ & $1.32 \pm 0.02$ & $86 \pm 3$ \\
& $(-)$ & $1.61 \pm 0.02$ & $1.37 \pm 0.02$ & $101 \pm 4$
\end{tabular}

$(+) \quad 1.55 \pm 0.02 \quad 1.38 \pm 0.01 \quad 92 \pm 3$

$(-) \quad 1.62 \pm 0.02 \quad 1.40 \pm 0.01 \quad 104 \pm 4$

Compost

$(+) \quad 1.53 \pm 0.02 \quad 1.34 \pm 0.02 \quad 85 \pm 3$

\begin{tabular}{lllll}
\hline$(-)$ & $2.34 \pm 0.04$ & $1.51 \pm 0.02$ & $256 \pm 13$
\end{tabular}

Composition

$\begin{array}{llll}(+) & 2.27 \pm 0.06 & 1.44 \pm 0.02 & 214 \pm 13\end{array}$

$\begin{array}{llll}(-) & 2.29 \pm 0.06 & 1.46 \pm 0.02 & 242 \pm 17\end{array}$

Shrub

$\begin{array}{llll}(+) & 2.36 \pm 0.04 & 1.52 \pm 0.02 & 251 \pm 12\end{array}$

$(-) \quad 2.32 \pm 0.05 \quad 1.52 \pm 0.02 \quad 257 \pm 16$

Compost

$\begin{array}{lll}(+) & 2.33 \pm 0.05 & 1.45 \pm 0.02 \\ \end{array}$

\begin{tabular}{lllll}
\hline Composition & $(-)$ & $3.03 \pm 0.06$ & $1.91 \pm 0.04$ & $587 \pm 3$
\end{tabular}

$\begin{array}{llll}(+) & 2.97 \pm 0.11 & 1.77 \pm 0.06 & 508 \pm 44\end{array}$

$\begin{array}{llll}(-) & 3.01 \pm 0.08 & 1.75 \pm 0.05 & 547 \pm 37\end{array}$

Shrub

Compost

\begin{tabular}{|c|c|c|}
\hline & $3.03 \pm 0.07$ \\
\hline
\end{tabular}

$\begin{array}{llll}(-) & 2.96 \pm 0.07 & 1.89 \pm 0.05 & 568 \pm 35\end{array}$

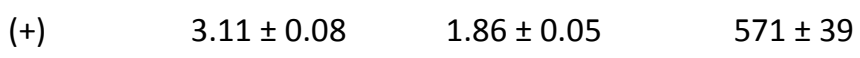
Diameter $(\mathrm{cm}) \quad$ Height $(\mathrm{m}) \quad$ Volume $\left(\mathrm{cm}^{3}\right)$

\begin{tabular}{lllll}
\hline Composition & $(-)$ & $2.44 \pm 0.03$ & $1.48 \pm 0.02$ & $251 \pm 8$
\end{tabular}

2011

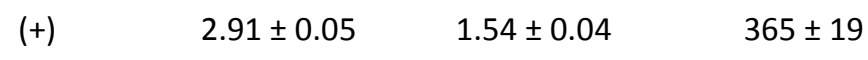

Shrub

$(-) \quad 2.50 \pm 0.04 \quad 1.50 \pm 0.02 \quad 270 \pm 11$

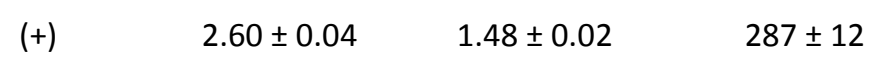




\begin{tabular}{|c|c|c|c|c|c|}
\hline & Comnost & $(-)$ & $2.51 \pm 0.04$ & $1.48 \pm 0.02$ & $272 \pm 11$ \\
\hline & & $(+)$ & $2.60 \pm 0.04$ & $1.51 \pm 0.02$ & $288 \pm 12$ \\
\hline & & $(-)$ & $3.63 \pm 0.07$ & $1.88 \pm 0.03$ & $801 \pm 39$ \\
\hline & Composition & $(+)$ & $4.62 \pm 0.15$ & $1.99 \pm 0.05$ & $1342 \pm 120$ \\
\hline & & $(-)$ & $3.68 \pm 0.10$ & $1.83 \pm 0.04$ & $854 \pm 65$ \\
\hline 2012 & Shrub & & & & \\
\hline & & $(+)$ & $4.05 \pm 0.09$ & $1.97 \pm 0.03$ & $1009 \pm 57$ \\
\hline & & $(-)$ & $3.56 \pm 0.08$ & $1.81 \pm 0.04$ & $755 \pm 43$ \\
\hline & Compost & $(+1)-1$ & $428+011$ & $203+004$ & $1172+80$ \\
\hline & & $(-)$ & $4.86 \pm 0.09$ & $2.48 \pm 0.05$ & $1847 \pm 84$ \\
\hline & Composition & & & & \\
\hline & & $(+)$ & $6.11 \pm 0.17$ & $2.73 \pm 0.08$ & $3077 \pm 219$ \\
\hline & & $(-)$ & $5.07 \pm 0.12$ & $2.41 \pm 0.05$ & $1999 \pm 126$ \\
\hline 2013 & Shrub & & & & \\
\hline & & $(+)$ & $5.26 \pm 0.11$ & $2.66 \pm 0.06$ & $2296 \pm 120$ \\
\hline & & $(-)$ & $4.73 \pm 0.09$ & $2.40 \pm 0.05$ & $1677 \pm 83$ \\
\hline & Compost & & & & \\
\hline & & $(+)$ & $5.77 \pm 0.13$ & $2.73 \pm 0.06$ & $2792 \pm 159$ \\
\hline
\end{tabular}

\footnotetext{
${ }^{1}$ The number of replicates are as follows: For $Q$. rubra: two species composition, $n=335$; six species composition, $n=103$; no shrubs, $n=221$; shrubs, $n=217$; no compost, $n=257$; compost, $n=181$; For T. americana: two species composition, $n=337$; six species composition, $n=105$; no shrubs, $n=$ 220; shrubs, $\mathrm{n}=222$; no compost, $\mathrm{n}=255$; compost, $\mathrm{n}=187$.
}

${ }^{2}$ For the composition treatment, (-) indicates two species plots, $(+)$ indicates six species plots. 
Table S3: Coefficients and $P$ values retained in the best-fit statistical models for treatment effects on the growth in diameter, height, and stem volume for (a) Quercus rubra and (b) Tilia Americana. Significant treatment effects $(P<0.05)$ are shown in bold text.

a) Quercus rubra Coeff. Pvalue

\begin{tabular}{lcc}
\hline (A) Diameter $(\mathrm{cm})$ & & \\
\hline Intercept & 0.985 & $<0.001$ \\
Shrub & -0.072 & 0.225 \\
Compost & -0.3140 & $\mathbf{0 . 0 4 5}$ \\
Year & 0.661 & $<0.001$ \\
Compost x Shrub & $\mathbf{0 . 2 0 6}$ & $\mathbf{0 . 0 2 6}$ \\
Compost x Year & $\mathbf{0 . 1 2 1}$ & $<0.01$
\end{tabular}

\begin{tabular}{lcc}
\hline (B) Height $(\mathrm{m})$ & & \\
\hline Intercept & 1.132 & $<0.001$ \\
Shrub & $-\mathbf{0 . 1 2 2}$ & $\mathbf{0 . 0 3 1}$ \\
Year & $\mathbf{0 . 1 8 7}$ & $<0.001$ \\
Shrub x Year & $\mathbf{0 . 1 1 1}$ & $<0.001$ \\
\hline
\end{tabular}

(C) Volume $\left(\mathrm{cm}^{3}\right)$

\begin{tabular}{lll}
\hline Intercept & $-154.840<0.001$
\end{tabular}

$\begin{array}{lll}\text { Shrub } & -23.48 & 0.318\end{array}$

$\begin{array}{lll}\text { Compost } & -56.61 & 0.2344\end{array}$

Year $\quad 232.75<0.001$

Shrub x Compost $\quad 88.72 \quad<0.01$

b) Tilia americana Coeff. $\quad P$ value

(A) Diameter $(\mathrm{cm})$

\begin{tabular}{lcc}
\hline Intercept & 1.241 & $<0.001$ \\
Composition & 0.394 & 0.12
\end{tabular}




\begin{tabular}{|c|c|c|}
\hline Shrub & 0.185 & 0.073 \\
\hline Compost & -0.483 & 0.041 \\
\hline Year & 1.05 & $<0.001$ \\
\hline Composition x Year & 0.291 & $<0.001$ \\
\hline Composition x Shrub & -0.389 & 0.031 \\
\hline Shrub x Compost & 0.341 & 0.029 \\
\hline Compost x Year & 0.42 & $<0.001$ \\
\hline \multicolumn{3}{|l|}{ (B) Height (m) } \\
\hline Intercept & 1.094 & $<0.001$ \\
\hline Shrub & -0.21 & $<0.01$ \\
\hline Compost & -0.177 & 0.138 \\
\hline Year & 0.381 & $<0.001$ \\
\hline Shrub x Compost & 0.163 & 0.032 \\
\hline Shrub x Year & 0.135 & $<0.001$ \\
\hline Compost x Year & 0.162 & $<0.001$ \\
\hline \multicolumn{3}{|l|}{ (C) Volume $\left(\mathrm{cm}^{3}\right)$} \\
\hline Intercept & -275.36 & 0.085 \\
\hline Composition & -627.35 & 0.015 \\
\hline Shrub & -238.87 & 0.112 \\
\hline Compost & -757.74 & $<0.01$ \\
\hline Year & 549.45 & $<0.001$ \\
\hline Composition $\mathrm{x}$ Compost & 467.53 & 0.107 \\
\hline Shrub x Compost & 276.45 & 0.031 \\
\hline Composition x Year & 448.84 & $<0.001$ \\
\hline Shrub x Year & 142.7 & 0.024 \\
\hline Compost x Year & 459.99 & $<0.001$ \\
\hline
\end{tabular}



Table S4: Means $\pm \mathrm{SE}^{1}$ for individual tree diameter, height, and stem volume for each treatment for (a) Celtis occidentalis, (b) Carya spp., (c) Prunus serotina, (d) Quercus alba

a) Celtis occidentalis

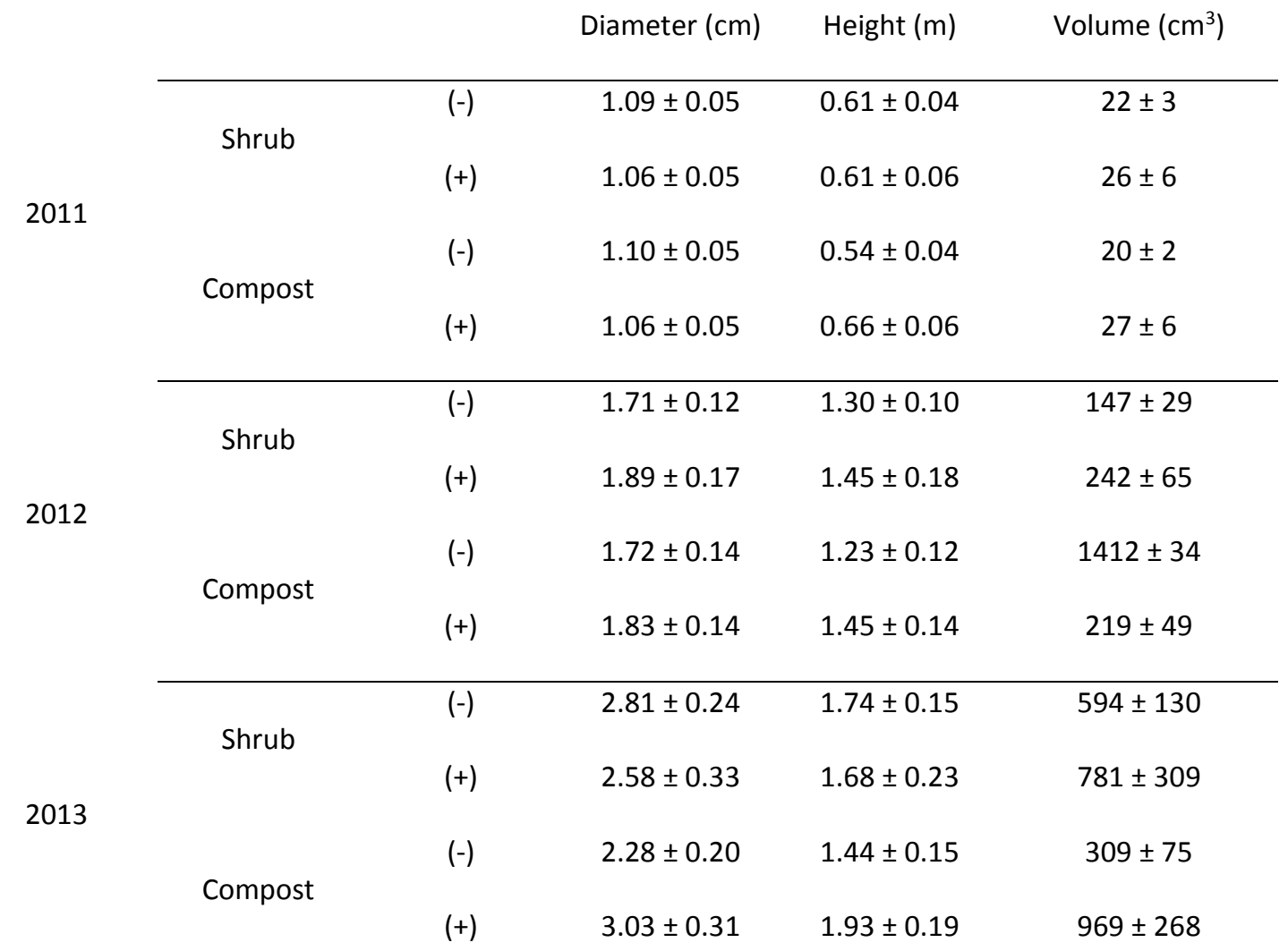

b) Carya spp.

\begin{tabular}{cccc} 
& Diameter $(\mathrm{cm})$ & Height $(\mathrm{m})$ & Volume $\left(\mathrm{cm}^{3}\right)$ \\
\hline$(-)$ & $1.66 \pm 0.04$ & $1.30 \pm 0.04$ & $103 \pm 9$
\end{tabular}

Shrub

2011

(+) $\quad 1.75 \pm 0.05 \quad 1.29 \pm 0.05 \quad 110 \pm 8$

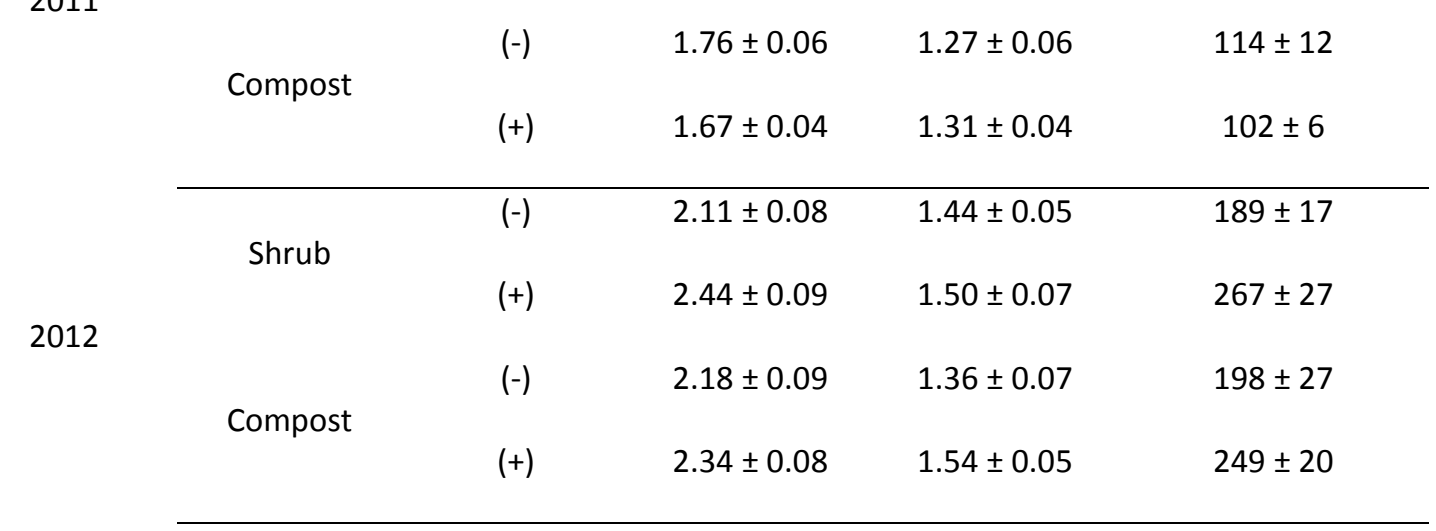




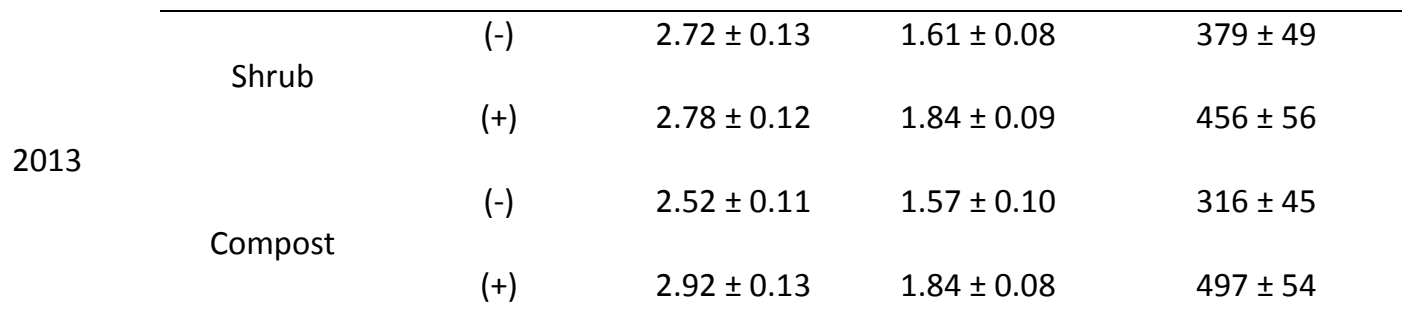

c) Prunus serotina

\begin{tabular}{|c|c|c|c|c|c|}
\hline & & & Diameter $(\mathrm{cm})$ & Height (m) & Volume $\left(\mathrm{cm}^{3}\right)$ \\
\hline \multirow{7}{*}{2011} & \multirow{3}{*}{ Shrub } & $(-)$ & $2.02 \pm 0.04$ & $1.45 \pm 0.04$ & $162 \pm 10$ \\
\hline & & & & & \\
\hline & & $(+)$ & $2.05 \pm 0.06$ & $1.46 \pm 0.05$ & $177 \pm 15$ \\
\hline & \multirow{4}{*}{ Compost } & & & & \\
\hline & & $(-)$ & $2.01 \pm 0.06$ & $1.43 \pm 0.04$ & $162 \pm 12$ \\
\hline & & & & & \\
\hline & & $(+)$ & $2.04 \pm 0.04$ & $1.47 \pm 0.05$ & $175 \pm 13$ \\
\hline \multirow{7}{*}{2012} & \multirow{3}{*}{ Shrub } & $(-)$ & $3.25 \pm 0.15$ & $1.80 \pm 0.08$ & $630 \pm 76$ \\
\hline & & & & & \\
\hline & & $(+)$ & $3.22 \pm 0.16$ & $2.01 \pm 0.09$ & $714 \pm 96$ \\
\hline & \multirow{4}{*}{ Compost } & & & & \\
\hline & & $(-)$ & $3.09 \pm 0.19$ & $1.88 \pm .10$ & $630 \pm 100$ \\
\hline & & & & & \\
\hline & & $(+)$ & $3.33 \pm 0.13$ & $1.94 \pm 0.08$ & $700 \pm 77$ \\
\hline \multirow{7}{*}{2013} & \multirow{3}{*}{ Shrub } & $(-)$ & $4.78 \pm 0.35$ & $2.39 \pm 0.15$ & $2148 \pm 363$ \\
\hline & & & & & \\
\hline & & $(+)$ & $4.86 \pm 0.30$ & $2.70 \pm 0.16$ & $2315 \pm 323$ \\
\hline & & & & & \\
\hline & \multirow{3}{*}{ Compost } & $(-)$ & $4.33 \pm 0.32$ & $2.42 \pm 0.17$ & $1754 \pm 335$ \\
\hline & & & & & \\
\hline & & $(+)$ & $5.18 \pm 0.31$ & $2.65 \pm 0.14$ & $2585 \pm 331$ \\
\hline
\end{tabular}

d) Quercus alba

\begin{tabular}{ccccc} 
& & Diameter $(\mathrm{cm})$ & Height $(\mathrm{m})$ & Volume $\left(\mathrm{cm}^{3}\right)$ \\
\hline Shrub & $(-)$ & $1.72 \pm .06$ & $1.08 \pm 0.03$ & $89 \pm 7$ \\
& $(+)$ & $1.72 \pm 0.05$ & $1.01 \pm 0.03$ & $81 \pm 6$ \\
Compost & $(-)$ & $1.73 \pm 0.06$ & $1.06 \pm 0.03$ & $86 \pm 6$ \\
& $(+)$ & $1.72 \pm 0.06$ & $1.03 \pm 0.03$ & $85 \pm 7$ \\
\hline Shrub & $(-)$ & $2.48 \pm 0.09$ & $1.15 \pm 0.03$ & $205 \pm 18$
\end{tabular}




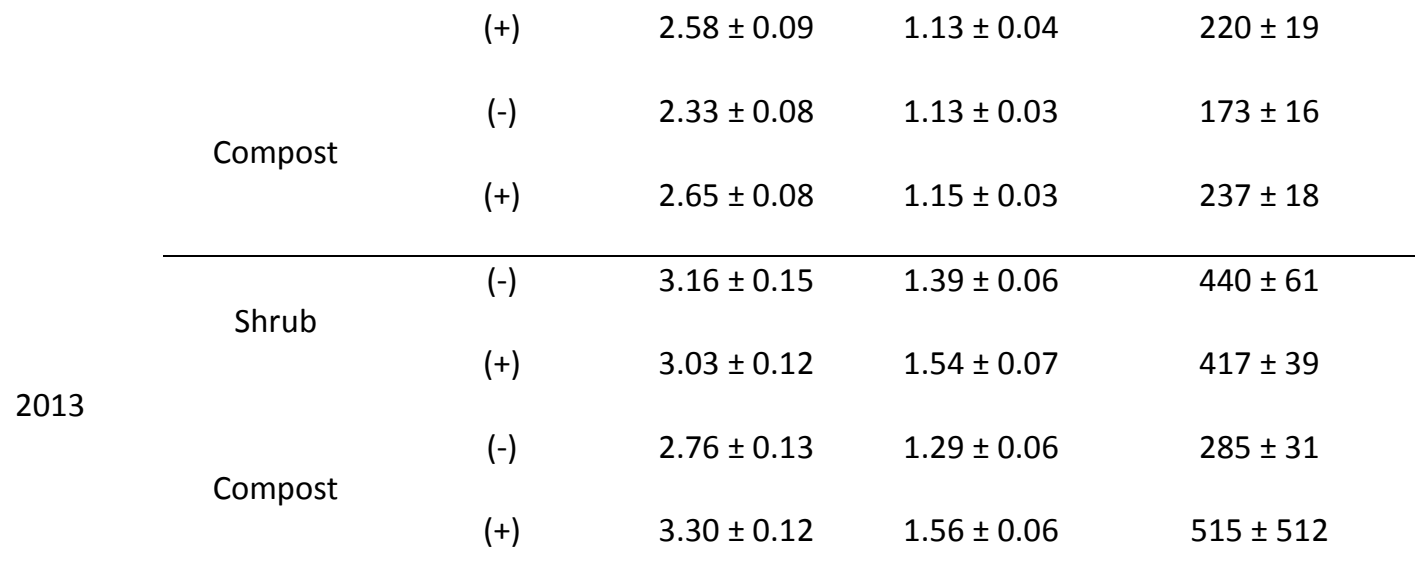

\footnotetext{
${ }^{1}$ The number of replicates are as follows: For $C$. occidentalis: no shrubs, $n=52$; shrubs, $n=52$; no compost, $\mathrm{n}=40$; compost, $\mathrm{n}=64$; for Carya spp.: no shrubs, $\mathrm{n}=51$; shrubs, $\mathrm{n}=52$; no compost, $\mathrm{n}=$ 40; compost, $n=63$; for $P$. serotina: no shrubs, $n=52$; shrubs, $n=52$; no compost, $n=40$; compost, $n=64$; for $Q$. alba: no shrubs, $n=52$; shrubs, $n=53$; no compost, $n=40$; compost, $n=65$.
} 
Table S5: Coefficients and $P$ values retained in the best-fit statistical models for treatment effects on the growth in diameter, height, and volume for (a) Celtis occidentalis, (b) Carya spp., (c) Prunus serotina, (d) Quercus alba. Significant treatment effects $(P<0.05)$ are shown in bold text.

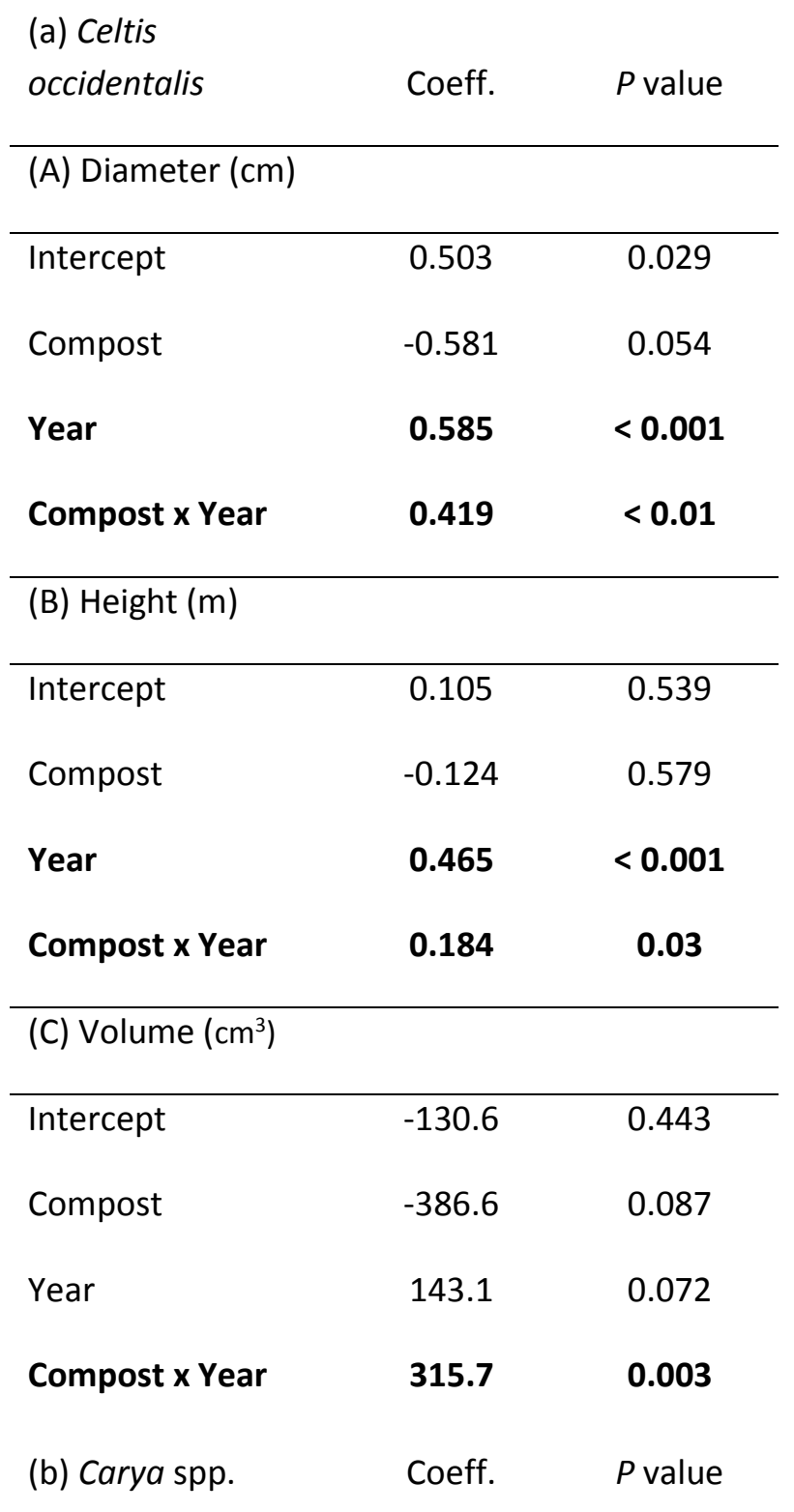

\begin{tabular}{lcc}
\hline \multicolumn{2}{l}{ (A) Diameter $(\mathrm{cm})$} & \\
\hline Intercept & 1.304 & $<0.001$ \\
Compost & -0.344 & 0.058 \\
Shrub & 0.17 & 0.072 \\
Year & $\mathbf{0 . 3 8}$ & $<\mathbf{0 . 0 0 1}$
\end{tabular}




\begin{tabular}{lll} 
Compost x Year & $\mathbf{0 . 2 4 5}$ & $<0.001$ \\
\hline (B) Height $(\mathrm{m})$ & & \\
\hline Intercept & 1.214 & $<0.001$ \\
Shrub & -0.268 & 0.057 \\
Compost & -0.189 & 0.211 \\
Year & $\mathbf{0 . 1 1}$ & $\mathbf{0 . 0 0 7}$ \\
Shrub x Compost & 0.271 & 0.058 \\
Shrub x Year & $\mathbf{0 . 0 9 6}$ & $\mathbf{0 . 0 2 7}$ \\
Compost x Year & $\mathbf{0 . 1}$ & $\mathbf{0 . 0 2 3}$ \\
\hline (C) Volume (cm $\left.{ }^{3}\right)$ & & \\
\hline Intercept & -21.52 & 0.701 \\
Compost & -118.47 & 0.091 \\
Shrub & 53.74 & 0.072 \\
Year & $\mathbf{1 0 1 . 1 7}$ & $<\mathbf{0 . 0 0 1}$ \\
Compost x Year & $\mathbf{9 5 . 3 6}$ & $<\mathbf{0 . 0 0 1}$
\end{tabular}

(c) Prunus serotina Coeff. Pvalue

\begin{tabular}{lll}
\hline (A) Diameter (cm) & & \\
\hline Intercept & 0.875 & 0.038 \\
Compost & -0.478 & 0.359 \\
Year & $\mathbf{1 . 1 2 3}$ & $<\mathbf{0 . 0 0 1}$ \\
Compost x Year & $\mathbf{0 . 4 2 7}$ & $<\mathbf{0 . 0 1}$ \\
\hline (B) Height (m) & & \\
\hline Intercept & 0.974 & $<0.001$ \\
Shrub & -0.138 & 0.372 \\
Year & $\mathbf{0 . 4 5 2}$ & $<\mathbf{0 . 0 0 1}$
\end{tabular}




\begin{tabular}{|c|c|c|}
\hline Shrub x Year & 0.146 & 0.025 \\
\hline \multicolumn{3}{|l|}{ (C) Volume $\left(\mathrm{cm}^{3}\right)$} \\
\hline Intercept & -705.830 & 0.047 \\
\hline Compost & -512.9 & 0.253 \\
\hline Year & 767.6 & $<0.001$ \\
\hline Compost x Year & 406.2 & 0.0153 \\
\hline (d) Quercus alba & Coeff. & $P$ value \\
\hline \multicolumn{3}{|l|}{ (A) Diameter $(\mathrm{cm})$} \\
\hline Intercept & 1.236 & $<0.001$ \\
\hline Compost & -0.267 & 0.212 \\
\hline Year & 0.52 & $<0.001$ \\
\hline Compost x Year & 0.277 & $<0.001$ \\
\hline \multicolumn{3}{|l|}{ (B) Height (m) } \\
\hline Intercept & 1.026 & $<0.001$ \\
\hline Shrub & -0.191 & 0.019 \\
\hline Compost & -0.194 & 0.028 \\
\hline Year & 0.061 & 0.063 \\
\hline Shrub x Year & 0.103 & $<0.01$ \\
\hline Compost x Year & 0.14 & $<0.001$ \\
\hline \multicolumn{3}{|l|}{ (C) Volume $\left(\mathrm{cm}^{3}\right)$} \\
\hline Intercept & -15.24 & 0.757 \\
\hline Compost & -131.61 & 0.038 \\
\hline Year & 98.05 & $<0.001$ \\
\hline Compost x Year & 114.3 & 0.0001 \\
\hline
\end{tabular}

